\title{
The freshwater red algae (Batrachospermales, Rhodophyta) of Africa and Madagascar I. New species of Kumanoa, Sirodotia and the new genus Ahidranoa (Batrachospermaceae)
}

\author{
Eberhard Fischer ${ }^{1 *}$, Johanna Gerlach², Dorothee Killmann ${ }^{1}$ \& Dietmar Quandt2*
}

\author{
Article info \\ Received: 4 Oct. 2019 \\ Revision received: 11 May 2020 \\ Accepted: 11 May 2020 \\ Published: 2 Jun. 2020 \\ Associate Editor \\ Nicolas Magain
}

\begin{abstract}
Our knowledge of the diversity of African freshwater red algae is rather limited. Only a few reports exist. During our field work in the last five years we frequently encountered freshwater red algae in streams in Rwanda and Madagascar. Here we describe four new species and one new genus of freshwater red algae from the Batrachospermales, based on morphological and molecular evidence: Kumanoa comperei from the Democratic Republic of the Congo and Rwanda is related to K. montagnei and K. nodiflora; Kumanoa rwandensis from Rwanda is related to K. ambigua and K. gudjewga; Sirodotia masoalensis is related to $S$. huillensis and $S$. delicatula; and the new genus and species Ahidranoa madagascariensis from Madagascar is sister to Sirodotia, Lemanea, Batrachospermum s.str. and Tuomeya. There is also evidence for the presence of Sheathia, which was recorded as yet-unidentifiable Chantransia stages. These are among the first new descriptions since 1899 from the African continent and since 1964 from Madagascar. A short history of the exploration of freshwater red algae from Africa and Madagascar is provided. All new taxa are accompanied by illustrations and observations on their ecology.
\end{abstract}

Key words: Batrachospermaceae, tropical Africa, Madagascar, taxonomy

\section{Introduction}

The history of the exploration of freshwater red algae in Africa and Madagascar

'Very little is known concerning the freshwater algae from Africa' (West \& West 1897). This is still true more than 120 years after that statement. While interest in the long-neglected group of freshwater red algae has increased in the Northern Hemisphere (e.g., Entwisle et al. 2009; Eloranta et al. 2011; Vis et al. 2012; Knappe \& Huth 2014; Salomaki et al. 2014), South America (e.g., Necchi 1990; Necchi et al. 2010, 2019) and Australia (e.g., Entwisle \& Foard 2007; Entwisle et al. 2016), there are only limited data available for Africa.

The first collection of a freshwater red alga from Africa was made by W. G. Schimper, who collected a Lemanea in 1840 in the Simien Mountains of Ethiopia ("in latere medio boreali montis Silke'). This specimen was subsequently described by Kützing (1849) as Lemanea abyssinica. The first species of Batrachospermum was

\footnotetext{
${ }^{1}$ Institute for Integrated Natural Sciences - Biology, University of Koblenz-Landau, Universitätsstraße 1, 56070 Koblenz, Germany

${ }^{2}$ Nees Institute for Biodiversity of Plants, University of Bonn, Meckenheimer Allee 170, 53115 Bonn, Germany

* Corresponding authors e-mail: efischer@uni-koblenz.de, quandt@ uni-bonn.de
}

published as B. patens (Suhr 1840) from Kroemsrivier (today Kromrivier) in the Cape region of South Africa, collected by Drège (without date). Szinte et al. (2020) place Batrachospermum patens into synonymy with Torularia atra (see below).

The next collections of freshwater red algae from Africa were made by Bishop Johann Christian Breutel in South Africa at the Herrenhut Mission of Gnadenthal (=Genadendal in Western Cape Province) in 1853-1854 (Rabenhorst 1855). Breutel collected the first two species of Batrachospermum from Africa, Batrachospermum africanum ('afrikanum') and Batrachospermum breutelii (Rabenhorst 1855). A few years later, a third species was described from this area: 'Batrachospermum dimorphum Kütz., im Paviansfluss bei dem Herrenhuter Missionsort Gnadenthal in Süd-Africa. Mitgetheilt vom Herrn Pfarrer Wenck in Neu-Dieten' (Kützing 1857). This name is currently regarded as a synonym of Batrachospermum breutelii (Rabenhorst 1855).

The most extensive collections of freshwater red algae in Africa were made by Friedrich Welwitsch between 1855 and 1860 in Angola. The results were published by West $\&$ West (1897) almost 40 years later. The recorded species are Batrachospermum angolense [= Sirodotia angolensis according to Guiry (2019) but considered a heterotypic 
synonym of Torularia atra (=Atrophycus ater) in the previous literature, e.g., Entwisle 1992], Batrachospermum nigrescens (Sirodotia nigrescens $=$ Torularia puiggariana), Batrachospermum gracillimum (=Kumanoa gracillima), Batrachospermum huillense (= Sirodotia huillensis), Hildenbrandia rivularis and $H$. angolensis. West $\&$ West (1897) remark that it is 'interesting to note that the earliest collection of algae made in Africa has been found to be more extensive and representative than any hitherto described' (West \& West 1897: 1-2). None of these species has been re-collected from Africa but they were later recorded from South America or Europe. One of the last new descriptions from the African continent is Batrachospermum bohneri (Schmidle 1899a) from Cameroon, which is assigned by its author to section Helminthosum and is said to have a large stalked trichogyne. Unfortunately it is not mentioned in the subsequent literature and is also omitted from AlgaeBase (Guiry 2019). As the type probably has been destroyed and the protologue is not accompanied by any illustration, it is considered a doubtful name here. Separately published illustrations from this material (Schmidle 1899b) led Szinte et al. (2020) to identify it as Montagnia macrospora. A collection from Rwanda by Johannes Mildbraed in 1907 was identified as Batrachospermum bohneri (Lemmermann 1914: Rugege Wald, kalter Quellbach des Rukarara) but the specimen was destroyed in Berlin and the record is considered doubtful. Several other red algae were collected at this locality during our research but no specimen matched the description of Batrachospermum bohneri.

In his review of the subaerial and freshwater algal flora of the Tropics, Fritsch (1907) listed for Africa the five species described by West and West (1897) and Schmidle (1899a) but ignored the records of Lemanea. Thus, nine species of freshwater red algae were known from tropical Africa in 1907, and for 112 years not much progress was made. Borge (1928) listed two species of Batrachospermum, B. dillenii (=Torularia atra) and B. vagum (=B. turfosum) from Tanzania (eastern Usambara, Kilimandscharo) but the identifications are considered doubtful, as no specimens could be retrieved, so they serve only as an indication that there are freshwater red algae present in the mountains of eastern Tanzania. The same is true for the record of Tuomeya fluviatilis (=T. americana) from eastern Usambara (Borge 1928). In some papers on the diversity of freshwater algae, Compère (1975) recorded Audouinella hermannii from Chad, and Da et al. (1999) and Alika \& Akoma (2012) listed Batrachospermum turfosum (as B. vagum) for the Ivory Coast and Nigeria, these latter records probably erroneous. By coincidence, another paper has just appeared independently (Szinte et al. 2020) in which the authors describe the new species Kumanoa bouwmanii, Sheathia murpheyi and Sirodotia kennedyi, all from Zambia, and they name a Chantransia stage as C. azurea from South Africa. They also give an overview of available herbarium specimens, mainly from BR and PC (abbreviations after Thiers 2019), the majority of which are not identifiable.

For South Africa, the taxon described by Suhr (1840) and the two species described by Rabenhorst (1855) are known, with the recent additions of Sirodotia suecica (Lam et al. 2012) and Kumanoa iriomotensis, collected in Western Cape Province in 2006 (Necchi \& Vis 2012). The only records of freshwater red algae from Madagascar are Batrachospermum gelatinosum (Fritsch 1914, record probably erroneous) and Nothocladus afroaustralis (Skuja 1964), known only from the Fort Dauphin region in southeastern Madagascar.

\section{Phylogenetic relationships of Batrachospermum and related genera}

With about 112 species recognized, the genus Batrachospermum with the type species $B$. gelatinosum was considered the most species-rich genus of freshwater red algae, and was divided into two subgenera (Batrachospermum, Acarposporophytum), the former containing eight sections (Kumano 2002). However, based on molecular data from phylogenetic studies (Vis et al. 1998; Vis \& Entwisle 2000; Vis et al. 2005; Entwisle et al. 2009), this genus has been shown to be paraphyletic. Early accepted segregates are Sirodotia and Nothocladus. Entwisle et al. (2009) proposed acceptance of different sections for the time being: Acarposporophytum, Aristata, Batrachospermum, Helminthoidea, Macrospora, the informal 'Australasica group', Setacea, and Turfosa and Virescentia. The sections Contorta and Hybrida were placed in the new genus Kumanoa (Entwisle et al. 2009). Subsequently, Salomaki et al. (2014) placed members of section Helminthoidea in the new genus Sheathia. More recently the new genus Nocturama (Entwisle et al. 2016) was erected, now comprising two species from Australia and South America (Necchi et al. 2016). In the first paper the genus Nothocla$d u s$, formerly containing three species from Madagascar and Australia (which now constitute section Nothocla$d u s$ ) was enlarged to comprise most of the old informal 'Australasica-group' with the new sections Australasicus, Theaquus and Kraftii, and also section Setaceus. Contrary to the arguments of Entwisle et al. (2016), Rossignolo and Necchi (2016) subsequently raised section Setacea to generic level and included three species. For nomenclatural reasons the generic name Setaceus had to be replaced by Atrophycus (Rossignolo et al. 2017). Wynne (2019) showed that the name Torularia (Bonnemaison 1828) has priority over Atrophycus, and thus the three recognized members of the former section Setacea were placed in the genus Torularia. Section Virescentia was raised to genus level under the name Virescentia (Necchi et al. 2018). Sections Acarposporophytum and Aristata were raised to generic status under the names Acarposporophycus and Visia (Necchi et al. 2019b), and section Macrospora to genus Montagnia (Necchi et al. 2019a). Two new genera were recently added: Volatus (Chapuis et al. 2017) with three species from North America and Europe, and the monotypic Lympha with Lympha mucosa (Evans et al. 2017). Thus the genus Batrachospermum s.str. comprises only Batrachospermum gelatinosum with a few related species, while section Turfosa is still not assigned to a definite genus and is thus kept as Batrachospermum s.l. For a summary of the taxonomic changes and the currently accepted taxonomy we refer to Table 1 . 
Table 1. Historical overview and currently accepted taxonomy of the Batrachospermaceae.

\begin{tabular}{|c|c|c|c|}
\hline Kumano 2002 & Entwisle et al. 2009 & Entwisle et al. 2016 & Accepted taxonomy \\
\hline $\begin{array}{l}\text { Batrachospermum } \\
\text { Subg. Acarposporophytum Necchi }\end{array}$ & $\begin{array}{l}\text { Batrachospermum } \\
\text { Sect. Acarposporophytum }\end{array}$ & - & Acarposporophycus Necchi et al. \\
\hline $\begin{array}{l}\text { Batrachospermum } \\
\text { Subg. Batrachospermum }\end{array}$ & - & - & - \\
\hline $\begin{array}{l}\text { Batrachospermum } \\
\text { Sect. Batrachospermum }\end{array}$ & $\begin{array}{l}\text { Batrachospermum } \\
\text { Sect. Batrachospermum }\end{array}$ & - & Batrachospermum Roth s.str. \\
\hline Batrachospermum Sect. Setacea & Batrachospermum Sect. Setacea & Nothocladus Sect. Setacea & $\begin{array}{l}\text { Torularia } \text { Bonnemaison } \\
\text { (= Setacea } \text { Rossignolo \& Necchi, } \\
\text { Atrophycus Rossignolo et al.) }\end{array}$ \\
\hline $\begin{array}{l}\text { Batrachospermum } \\
\text { Sect. Turfosa Sirodot }\end{array}$ & Batrachospermum Sect. Turfosa & - & Batrachospermum Sect. Turfosa \\
\hline $\begin{array}{l}\text { Batrachospermum } \\
\text { Sect. Virescentia } \text { Sirodot }\end{array}$ & $\begin{array}{l}\text { Batrachospermum } \\
\text { Sect. Virescentia }\end{array}$ & - & Virescentia \\
\hline $\begin{array}{l}\text { Batrachospermum Sect. Gonimo- } \\
\text { propagulum Sheath \& Wittick }\end{array}$ & - & - & $\begin{array}{l}\text { Batrachospermum Section Goni- } \\
\text { mopropagulum Sheath \& Wittick }\end{array}$ \\
\hline $\begin{array}{l}\text { Batrachospermum Sect. Hybrida } \\
\text { De Toni }\end{array}$ & Kumanoa Entwisle et al. & - & Kumanoa Entwisle et al. \\
\hline $\begin{array}{l}\text { Batrachospermum } \\
\text { Sect. Contorta Skuja }\end{array}$ & Kumanoa Entwisle et al. & - & Kumanoa Entwisle et al. \\
\hline $\begin{array}{l}\text { Batrachospermum } \\
\text { Sect. Aristata } \text { Skuja }\end{array}$ & $\begin{array}{l}\text { Batrachospermum Sect. } \\
\text { Aristata } \text { Skuja }\end{array}$ & - & Visia Necchi et al. \\
\hline $\begin{array}{l}\text { Batrachospermum } \\
\text { Subsect. Macrospora Kumano }\end{array}$ & $\begin{array}{l}\text { Batrachospermum Sect. Macro- } \\
\text { spora (Kumano) Entwisle et al. }\end{array}$ & - & Montagnia Necchi et al. \\
\hline ( & $\begin{array}{l}\text { Batrachospermum Sect. Helmin- } \\
\text { thoidea Sirodot ex De Toni }\end{array}$ & - & Sheathia Salomaki et al. \\
\hline- & $\begin{array}{l}\text { Batrachospermum } \\
\text { Australasica Group }\end{array}$ & Nothocladus Sect. Australasica & Nothocladus Skuja \\
\hline- & Nothocladus & Nothocladus Sect. Nothocladus & Nothocladus Skuja \\
\hline Sirodotia Kylin & Sirodotia Kylin & - & Sirodotia Kylin \\
\hline Tuomeya Harvey & Tuomeya Harvey & - & Tuomeya Harvey \\
\hline- & - & Nocturama Entwisle \& Vis & Nocturama Entwisle \& Vis \\
\hline- & - & - & Lympha J. R. Evans et al. \\
\hline- & - & - & Volatus I. S. Chapuis \& M. L. Vis \\
\hline- & Petrohua G. W. Saunders & - & Petrohua G. W. Saunders \\
\hline Lemanea Bory & Lemanea Bory & - & Lemanea Bory \\
\hline Paralemanea (Silva) Vis \& Sheath & $\begin{array}{l}\text { Paralemanea (Silva) Vis } \\
\text { \& Sheath }\end{array}$ & - & $\begin{array}{l}\text { Paralemanea (Silva) Vis } \\
\& \text { Sheath }\end{array}$ \\
\hline Psilosiphon Entwisle & Psilosiphon Entwisle & - & Psilosiphon Entwisle \\
\hline Ballia Harvey & $\begin{array}{l}\text { Balliopsis G. W. Saunders } \\
\text { \& Necchi }\end{array}$ & - & $\begin{array}{l}\text { Balliopsis G. W. Saunders } \\
\text { \& Necchi }\end{array}$ \\
\hline
\end{tabular}

Since 2011, several freshwater red algae have been collected from tropical Africa (Gabon, Rwanda, Burundi) and Madagascar. Most of them could not be identified with the available literature. The aim of this study is to reconstruct the phylogenetic relationships between these taxa based on molecular and morphological evidence, and to characterize the taxa collected in tropical Africa and Madagascar. In this first paper we deal with collections of the genera Ahidranoa, Kumanoa and Sirodotia from Rwanda and Madagascar, and we describe one genus and four species new to science. We also provide evidence for the occurrence of the genus Sheathia, albeit only collected as Chantransia stages.

\section{Material and methods}

Sampling and investigations

Freshwater red algae were sampled between 2014 and 2018 from four locations in Rwanda and two in Madagascar. Herbarium vouchers with specimens preserved in $70 \%$ alcohol were deposited in BR, TAN and KOBL (abbreviations after Thiers 2019, Table 2). Their morphology was examined and photographed with a KEYENCE VHX-S15 digital microscope.

\section{DNA isolation}

Silica-dried plant material was homogenized in a $2 \mathrm{ml}$ Eppendorf cap (round bottom) with two glass beads (ø $5 \mathrm{~mm}$ ) and a small amount (tip of spatula) of autoclaved sand at $30 \mathrm{hz}$ for $2 \mathrm{~min}$. using a TissueLyser II (QIAGEN, Venlo, Netherlands). From the obtained powder, genomic DNA was extracted using a NucleoSpin Plant II Kit (Marchery-Nagel, Düren, Germany), following the customized protocol of the supplier.

\section{Amplification and sequencing}

Amplification of COI followed Saunders (2005) using the primers GazF1 and GazR1, while new primers were designed for amplification of $r b c \mathrm{~L}$ ( $\mathrm{rbcL}-$ redF: TGCYAAAATGGGWTAYTGG; rbcS-redR: 


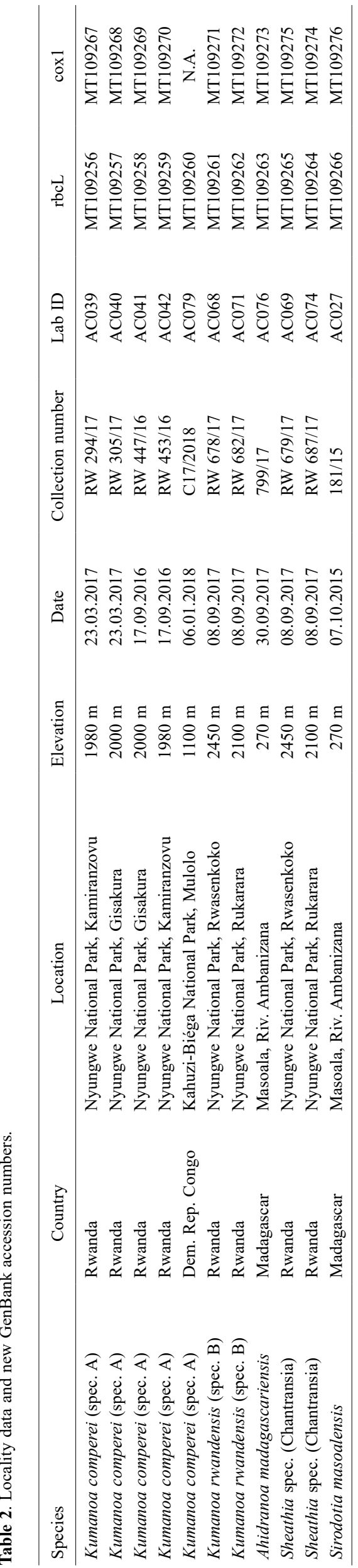

CCTTGTGTTARTCTCAC). All PCR reactions were performed in $25 \mu \mathrm{l}$ volumes for each sample. Each PCR reaction contained $1 \mu \mathrm{l}$ DNA $(>\sim 10 \mathrm{ng} / \mu \mathrm{l}), 10.35 \mu \mathrm{l}$ $\mathrm{H}_{2} \mathrm{O}, 5 \mu \mathrm{l} 5 \mathrm{x}$ Taq Flexi Buffer, $2.5 \mu \mathrm{l} 25 \mathrm{mM} \mathrm{MgCl}_{2}$, $4 \mu \mathrm{l}$ of dNTPs (each $1.25 \mathrm{mM}$ ), $1 \mu \mathrm{l}$ of the respective forward and reverse primer $(20 \mathrm{pm} / \mu \mathrm{l})$ and $0.15 \mu \mathrm{Taq}$ Polymerase ( 5 units $/ \mu \mathrm{l}$ ). The PCR profile for the $r b c \mathrm{~L}$ fragment comprised two steps: 1 cycle $\left(94^{\circ} \mathrm{C} 120 \mathrm{~s}, 50^{\circ} \mathrm{C}\right.$ $\left.60 \mathrm{~s}, 68^{\circ} \mathrm{C} 120 \mathrm{~s}\right)$ followed by 38 cycles $\left(94^{\circ} \mathrm{C} 30 \mathrm{~s}, 48^{\circ} \mathrm{C}\right.$ $60 \mathrm{~s}, 68^{\circ} \mathrm{C} 120 \mathrm{~s}$ ) and final extension of $20 \mathrm{~min}$. at $72^{\circ} \mathrm{C}$. For amplification of COI the following PCR profile was used: $94^{\circ} \mathrm{C} 3 \mathrm{~min}$. followed by 34 cycles $\left(94^{\circ} \mathrm{C} 60 \mathrm{~s}\right.$, $45^{\circ} \mathrm{C} 60 \mathrm{~s}, 72^{\circ} \mathrm{C} 60 \mathrm{~s}$ ) and final extension of $10 \mathrm{~min}$. at $72^{\circ} \mathrm{C}$. Newly generated sequences were deposited in GenBank (Table 2).

\section{Contig assembly, alignment and phylogenetic analyses}

Quality control of the pherograms, contig assembly and alignment was done in PhyDE1 (available at www.phyde. de). In order to place the African taxa in phylogenetic context, a representative set of freshwater red algae $r b c \mathrm{~L}$ and COI sequences were downloaded from GenBank (Table 3) and aligned with the newly generated sequences, using PhyDE1. Sampling was guided by Entwisle et al. (2009).

Maximum likelihood (ML) analyses were performed using RAxML-NG (Kozlov et al. 2019) via the RAxML BlackBox (raxml-ng.vital-it.ch), applying the GTR $+\Gamma$ + I model. Bootstrap analysis was performed with the automatic bootstrapping option in effect at a cutoff of 0.3 . Bayesian analyses were performed with MrBayes v.3.2.5 (Ronquist et al., 2012), applying the GTR $+\Gamma$ + I model. Four runs with four chains $\left(10^{7}\right.$ generations each) were run simultaneously, with chain sampling every 1000th generation. Tracer v.1.7.1 (Rambaut \& al., 2018) was used to examine log likelihoods to determine the effective sampling size and stationarity of the MCMC search. Calculations of the consensus tree, including clade posterior probability (PP), were performed using the relburnin function in MrBayes; that is, the first $25 \%$ of the trees were discarded. Consensus topologies and support values were compiled and drawn using TreeGraph v.2 (Stöver \& Müller, 2010). Bootstrap support (BS > 50) is depicted above and posterior probability $(\mathrm{PP}>0.8)$ below the branches of the maximum likelihood tree. Support values in the text are given as BS/PP.

\section{Phylogeny}

\section{Phylogenetic results}

The concatenated data set comprised 1943 characters ( $r b c \mathrm{~L}:$ 1280; COI: 663) for 68 taxa (Tables 2 \& 3, Fig. 1, $\mathrm{S} 1, \mathrm{~S} 2)$. Bayesian inference resulted in a resolved and well-supported phylogeny of the Batrachospermales. In principle, two large sister clades were resolved, one containing Kumanoa, Virescentia and Visia (clade A; 55/0.95), the other Batrachospermum, Tuomeya, Lemanea, Sirodotia, Sheathia, Nocturama, Torularia and Nothocladus (clade B; 88/1). Within the latter clade, Nocturama, 
Table 3. Accession numbers of $r b c L$ and COI gene sequences used from GenBank.

\begin{tabular}{|c|c|c|}
\hline \multirow{2}{*}{ Species } & \multicolumn{2}{|c|}{ Accession number } \\
\hline & $r b c L$ & $\mathrm{COI}$ \\
\hline Audouinella hermannii & KC134346 & - \\
\hline Balbiania investiens & AF132293 & KM055323 \\
\hline Bangia atropurpurea & DQ408162 & DQ191330 \\
\hline Batrachospermum spermatoinvolucrum & AF029146 & - \\
\hline Bostrychia arbuscula & KM502821 & KM502796 \\
\hline Bostrychia moritziana & AY920809 & MF093965 \\
\hline Bostrychia scorpioides & AY920825 & MF094019 \\
\hline Chantransia azurea & MN974515 & MN974520 \\
\hline Hildenbrandia rubra & K-284724 & KF649304 \\
\hline Kumanoa abilii & GQ368883 & JN604915 \\
\hline Kumanoa ambigua & AY423390 & EU095970 \\
\hline Kumanoa americana & $\mathrm{KX} 284725$ & JN604910 \\
\hline Kumanoa bouwmanii & MN974516 & MN974521 \\
\hline Kumanoa breviarticulata & GQ368886 & EU636718 \\
\hline Kumanoa capensis & JX504698 & $J-504695$ \\
\hline Kumanoa cipoensis & GQ368887 & JN604919 \\
\hline Kumanoa curvata & JN590012 & JN604925 \\
\hline Kumanoa equisetoidea & GQ368889 & EU636716 \\
\hline Kumanoa globospora & GQ368891 & JN604923 \\
\hline Kumanoa gracillima & AY423395 & JN604927 \\
\hline Kumanoa gudjewga & JN590003 & JN604908 \\
\hline Kumanoa intorta & AY423397 & EU636717 \\
\hline Kumanoa iriomotensis & JN590011 & - \\
\hline Kumanoa louisianae & JN590005 & JN604924 \\
\hline Kumanoa montagnei & AY423396 & EU636713 \\
\hline Kumanoa nodiflora & AY423398 & EU636714 \\
\hline Kumanoa skujana & JN590008 & JN604922 \\
\hline Kumanoa tabagatenensis & JN590009 & JN604914 \\
\hline Kumanoa virgato-decaisneana & AF029148 & - \\
\hline Lemanea fluviatilis & AF029150 & KC130145 \\
\hline Lemanea fucina & KJ825959 & KU672391 \\
\hline Nocturama antipodites & KT802839 & KT802754 \\
\hline Nocturama novamundensis & KX764640 & - \\
\hline Nothocladus discors & AF257778 & KT802759 \\
\hline Nothocladus kraftii & KT802854 & KT802760 \\
\hline Nothocladus pseudogelatinosus & AF209983 & KT802761 \\
\hline Nothocladus wattsii & AF209986 & KT802765 \\
\hline Sheathia boryana & JX669773 & JX669707 \\
\hline Sheathia confusa & DQ393133 & JXX669712 \\
\hline Sheathia heterocortica & DQ393136 & EU636740 \\
\hline Sheathia involuta & AF029143 & - \\
\hline Sheathia murpheyi & MN974517 & MN974522 \\
\hline Sirodotia aff. huillensis & JF344717 & - \\
\hline Sirodotia delicatula & KC951862 & KF010486 \\
\hline Sirodotia huillensis & AF126410 & EU636739 \\
\hline Sirodotia kennedyi & MN974518 & - \\
\hline Sirodotia suecica & AF029158 & EU636737 \\
\hline Thorea hispida & KC511078 & KC511076 \\
\hline Torularia (Nothocladus) atra NZ & KT802841 & KT802756 \\
\hline Torularia (Nothocladus) atra ZA & MN974519 & MN974525 \\
\hline Torularia (Setacea) atro-brasiliensis & KT183023 & KT894749 \\
\hline Torularia (Setacea) puiggariana & KP203886 & KX703028 \\
\hline Tuomeya americana & AF029159 & KM055330 \\
\hline Virescentia viride-brasiliense & KM097039 & KM260002 \\
\hline Visia cayennensis & AY423392 & EU095971 \\
\hline
\end{tabular}

Sheathia, Torularia and Nothocladus, as well as a new genus, build a grade towards a strongly supported core clade (98/1) consisting of Batrachospermum, Tuomeya, Lemanea and Sirodotia. The African taxa, including the samples from Madagascar, are resolved in three different genera or are placed solitary (AC076) (Fig. 1). In Nyungwe National Park (Rwanda), two different species were found: one (K. rwandensis) clusters as sister to a clade consisting of Kumanoa ambigua, K. abilii and K. gudjewga, while the second (K. comperei) is sister to Kumanoa bouwmanii within a clade including Kumanoa montagnei and $K$. nodiflora. Kumanoa comperei is also found in the Democratic Republic of the Congo (AC079); it retains a sister group relation to the samples from Rwanda. The two samples from Madagascar (Masoala, Riv. Ambanizana) are resolved with significant support in clade B. While one sample (AC027, Sirodotia masoalensis) was resolved within Sirodotia as sister to S. kennedyi, the other (AC076, Ahidranoa madagascariensis) was resolved sister to the 'Batrachospermum-Lemanea-Sirodotia-Tuomeya' clade. In addition, the two Chantransia stages from Nyungwe National Park (Rwanda) are resolved within Sheathia sister to Sheathia murpheyi with maximal support (Fig. 1). It is noteworthy that both Torularia atra samples do not form a clade.

\section{Phylogenetic discussion}

The well-resolved and highly supported phylogeny of the Batrachospermales indicates that the current concept of the generic boundaries seems to be settled. All genera in which more than one taxon was included, such as Kumanoa, Batrachospermum, Lemanea, Sirodotia, Sheathia, Nocturama, Torularia and Nothocladus, are monophyletic and receive significant if not maximal support. Specifically, this new analysis supports recognition of the genus Torularia, as proposed by Rossignolo $\&$ Necchi (2016), which based on an earlier tree (Entwisle et al. 2016) would have resulted in a paraphyletic Nothocladus. However, our tree has limited taxa sequenced within the Nothocladus clade, and recognition of Torularia still runs counter to the concern raised in Entwisle et al. (2016) around the proliferation of less informative small genera. With respect to Batrachospermum more analyses need to be done, as indicated by Entwisle et al. (2009). The resolution of both Madagascan specimens within the 'Batrachospermum-Lemanea-Sirodotia' clade points to an interesting aspect related to the speciation and biogeography of red algae on the island, requiring further investigations.

\section{Taxonomy}

\section{The genus Kumanoa}

The genus Kumanoa (Entwisle et al. 2009) was proposed to accommodate the members of Batrachospermum sections Contorta and Hybrida. One of the main distinguishing characters is the twisted or curved carpogonial branch. An expanded molecular phylogeny of Kumanoa was provided by Vis et al. (2012), with additions by Necchi et al. 
(2010). At present, 35 species are accepted, and the genus shows the highest diversity in tropical and subtropical regions (Necchi \& Vis 2012). Only 13 species occur on more than one continent, and the majority of taxa show a narrow distribution, often known only from the type locality. According to Necchi \& Vis (2012), 20 species are narrow endemics: five species are endemic to Brazil, four to Australia, three each to Portugal and the USA, two to French Guiana, and one each to China, Hawaii and Papua New Guinea. Ganesan and West (2013) attributed seven

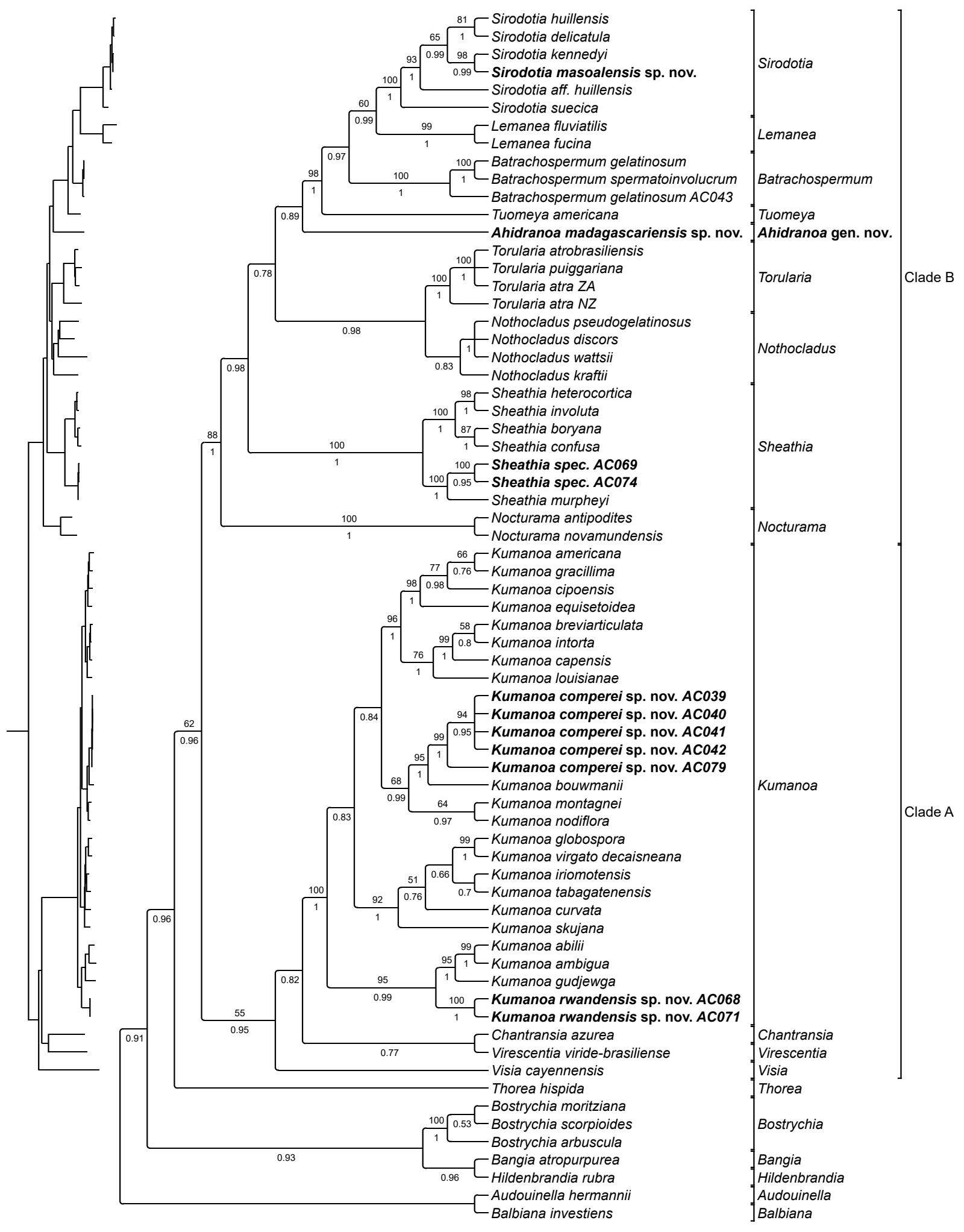

Figure 1. Likelihood tree based on concatenated $r b c \mathrm{~L}$ and COI sequences. The numbers associated with the nodes indicate support values, while maximum likelihood bootstrap support $(\mathrm{BS}>50)$ is depicted above the branches; posterior probability $(\mathrm{PP})$ for the Bayesian analysis can be found below them. The phylogram structure is indicated next to the ML tree. 
further species from India to Kumanoa, most of them known only from the type specimens, but their treatment relied entirely on literature studies, without consulting the relevant herbarium material. Johnston et al. (2014) added two further species from Indonesia. Szinte et al. (2020) describe Kumanoa bouwmanii from Northern Province, Zambia. Here we describe two new species from Rwanda and the Democratic Republic of the Congo, based on morphological and molecular evidence.

Kumanoa comperei Eb. Fisch., Killmann \& D. Quandt, sp. nov.

(Figs 2-4)

Diagnosis: Differs from Kumanoa montagnei in the shorter trichogyne, the carposporophyte higher than the whorls, sometimes two per whorl, and the secondary fascicles usually shorter than primary fascicles. It differs from $K$. nodiflora in the well-developed whorls. It differs from $K$. bouwmanii in the shape of the trichogyne.

Type: Rwanda, Western Province, Nyungwe National Park, stream in montane forest $\mathrm{S}$ of Kamiranzovu Swamp, along main road RN6, 2²9'09.14"S, 2909'55.37"E, 2102 m, Fischer RW 294/17 (AC 039), 23 March 2017 (BR - holotype; KOBL isotype).

Description. Plants moderately mucilaginous, thalli 3-14 cm high, branching irregular and abundant. Whorls reduced, composed of primary fascicles, 157-389 $\mu \mathrm{m}$ in diameter, barrel-shaped or obconic, slightly distant to confluent with age. Internode 120-190 $\mu \mathrm{m}$ long. Primary fascicles straight, with $7-8$ cell-storeys. Secondary fascicles abundant, covering the entire internode, usually shorter than the primary fascicles, $2-3(-8)$ cell-storeys.

Monoecious. Spermatangia spherical, $5-6 \mu \mathrm{m}$ in diameter, on primary and secondary fascicles. Carpogonial branches helically twisted, 35-38 $\mu \mathrm{m}$ long, composed of 4-6 cells, involucral filaments short, dense, carpogonia 25-35 $\mu \mathrm{m}$ long, trichogynes club-shaped, 25-30 $\times 10 \mu \mathrm{m}$, unstalked. Carposporophytes 1(-2) per whorl, hemispherical, usually higher than whorls, dense, 270-300 $\mu \mathrm{m}$ long, 210-250 $\mu \mathrm{m}$ in diameter, gonimoblast filaments 6-8 cell-storeys, carposporangia obovoid or elliptical, $5-7 \times 4-5 \mu \mathrm{m}$.

Ecology and distribution. Kumanoa comperei occurs in small acidic streams in montane forest between 1100 and $2100 \mathrm{~m}$. The streams are slow-flowing and half-shaded, with usually no aquatic vegetation except an unidentified Cladophora species at very low abundance. No aquatic bryophytes have been observed. So far the new species is known only from two localities in Nyungwe National Park in Rwanda and one locality in Kahuzi-Biéga-National Park in the Democratic Republic of the Congo.

Etymology. The species is dedicated to Pierre Compère (1934-2016), algologist at the National Botanical Garden of Meise, Belgium, who published numerous papers on African algae and a flora of freshwater red algae for Belgium.

Notes. In the phylogenetic tree (Fig. 1), Kumanoa comperei is sister to the almost simultaneously published Kumanoa bouwmanii (Szinte et al. 2020) but differs morphologically in the shape of the trichogyne, and molecularly in having distinct genetic differences. While among Kumanoa comperei samples the $r b c \mathrm{~L}$ sequences are identical and for COI the divergence is only $0.4 \%$, the differences from Kumanoa bouwmanii are conspicuous ( $r b c \mathrm{~L}: 2,6 \%$; COI: $7.3 \%$ ) and fall in the range of the observed divergence between species in the genus Kumanoa (rbcL: 1.5-8.4\%; COI: 3.2-16.2\%). Kumanoa comperei-K. bouwmanii cluster with Kumanoa montagnei (Entwisle et al. 2009) (=Batrachospermum guyanense nom. illeg.) and K. nodiflora (Entwisle et al. 2009). Kumanoa montagnei has long carpogonia, usually more than $45 \mu \mathrm{m}(-65 \mu \mathrm{m})$ in length, and loose carposporophytes $150-230 \mu \mathrm{m}$ in diameter, and unstalked long cylindrical or club-shaped trichogynes. Kumanoa comperei has carpogonia 25-35 $\mu \mathrm{m}$ long, trichogynes club-shaped, $25-30 \times 10 \mu \mathrm{m}$, unstalked, and carposporophytes not exceeding $160 \mu \mathrm{m}$ in diameter. Kumanoa nodiflora has reduced whorls and dense carposporophytes 200-400 $\mu \mathrm{m}$ in diameter that are higher than the whorl radius, and large carposporangia $15-20 \mu \mathrm{m}$ in length (vs. 5-7 $\mu \mathrm{m}$ in $K$. comperei).

Specimens examined. DEMOCRATIC REPUBLIC OF THE CONGO. Kahuzi-Bièga National Park, Mulolo, $1100 \mathrm{~m}$ (AC 079), B. \& L. Dumbo C17/2018, 6 January 2018 (KOBL). RWANDA, Western Province, Nyungwe National Park, stream in montane forest $\mathrm{S}$ of Kamiranzovu Swamp, along main road RN6, 2²9'09.14"S, 2909'55.37"E, 2102 m, Fischer RW 453/16 (AC 042), 17 September 2016 (BR, KOBL); Western Province, Nyungwe National Park, stream in montane forest near main road RN6 SE of Gisakura, $2^{\circ} 27^{\prime} 54.27^{\prime \prime} \mathrm{S}, 2^{\circ} 06^{\prime} 02.93^{\prime \prime} \mathrm{E}$, 1909 m, E. Fischer RW 305/17 (AC 040), 23 March 2017 (KOBL); ibid. E. Fischer 447/16 (AC 041), 17 September 2016 (KOBL).

Kumanoa rwandensis Eb. Fisch., Killmann \& D. Quandt, sp. nov.

(Figs 5-6)

Diagnosis: The new species differs from Kumanoa ambigua and $K$. gudjewga in the distinctly shorter secondary fascicles and the carposporophyte being as high or higher than the whorl radius.

Type: Rwanda, Southern Province, Nyungwe National Park, Rwasenkoko stream in Rwasenkoko Swamp, along main road RN6, 2 ${ }^{\circ} 31^{\prime} 43.60^{\prime \prime} \mathrm{S}, 29^{\circ} 21^{\prime} 12.62^{\prime \prime} \mathrm{E}, 2338 \mathrm{~m}$, E. Fischer 678/17 (AC 068), 8 September 2017 (BR - holotype; KOBL - isotype).

Description. Plants moderately mucilaginous, thalli $3-3.5 \mathrm{~cm}$ high, branching irregular and abundant. Whorls well developed, composed of primary fascicles, 360$548 \mu \mathrm{m}$ in diameter, barrel-shaped or obconic, slightly distant to confluent with age. Internodes 190-210 $\mu \mathrm{m}$ long. Primary fascicles straight, with 10-11 cell-storeys. Secondary fascicles abundant, covering the entire internode, usually shorter than the primary fascicles, 2-3 cell-storeys.

Monoecious. Spermatangia spherical, 5-6 $\mu \mathrm{m}$ in diameter, on primary and secondary fascicles. Carpogonial branches helically twisted, 34-38 $\mu \mathrm{m}$ long, composed of 5-6 cells, involucral filaments short, dense, carpogonia up to $32-38(-71) \mu \mathrm{m}$ long, trichogynes club-shaped, $10-12 \mu \mathrm{m}$ in diameter, unstalked. Carposporophytes $1(-2)$ per whorl, hemispherical, usually higher than whorls, 

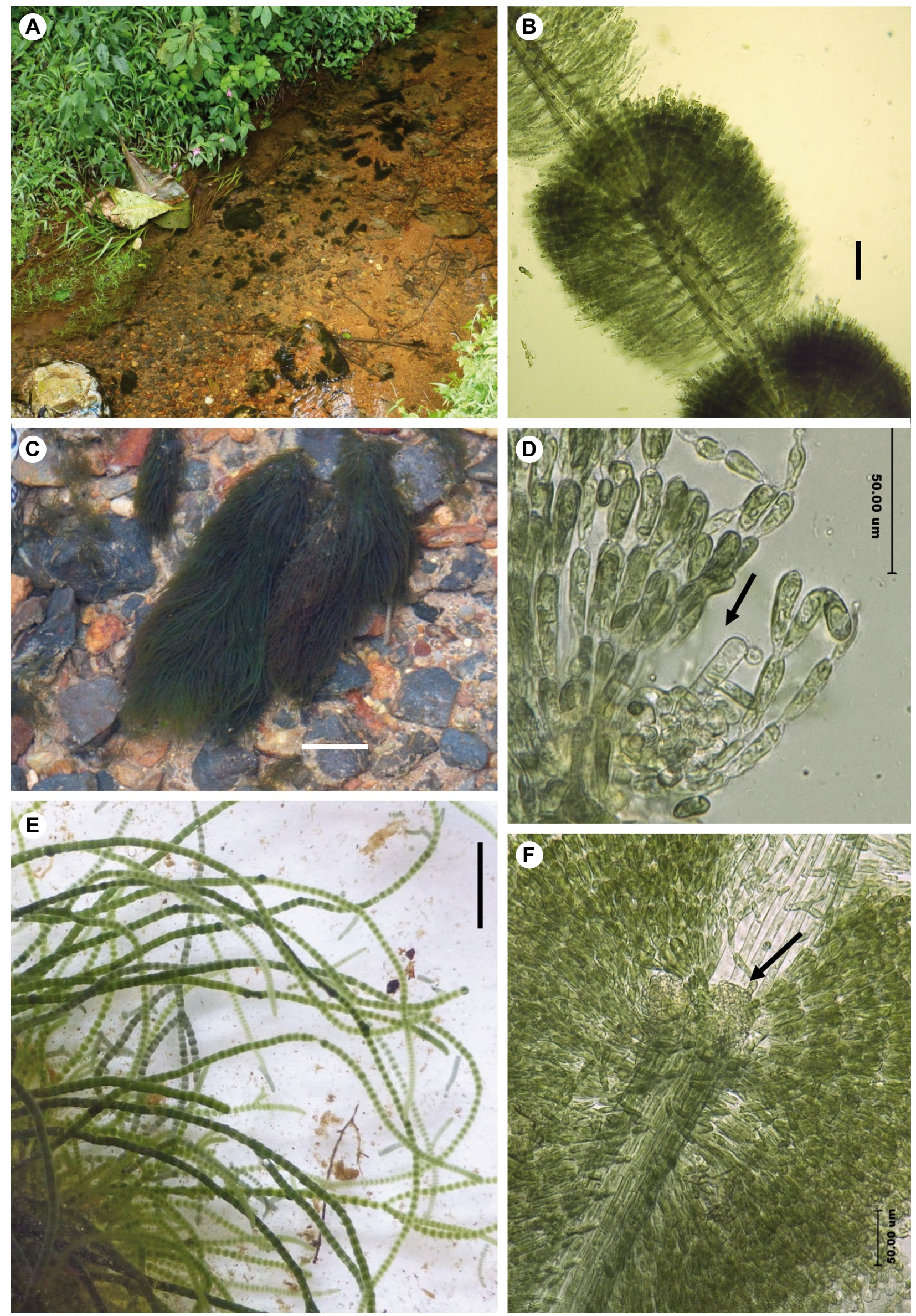

Figure 2. Kumanoa comperei. A - habitat in Kamiranzovu stream, Rwanda; B - whorls; C - habit in situ, Kamiranzovu stream; D - carpogonium with trichogyne (arrow); $\mathrm{E}$ - detail of habit; $\mathrm{F}$ - detail of whorl, showing primary and secondary fascicles and carpogonium (arrow). (A-F, Fischer RW 453/16, AC 042). Scales: B, D-F $=50 \mu \mathrm{m} ; \mathrm{C}, \mathrm{E}=1 \mathrm{~cm}$. 


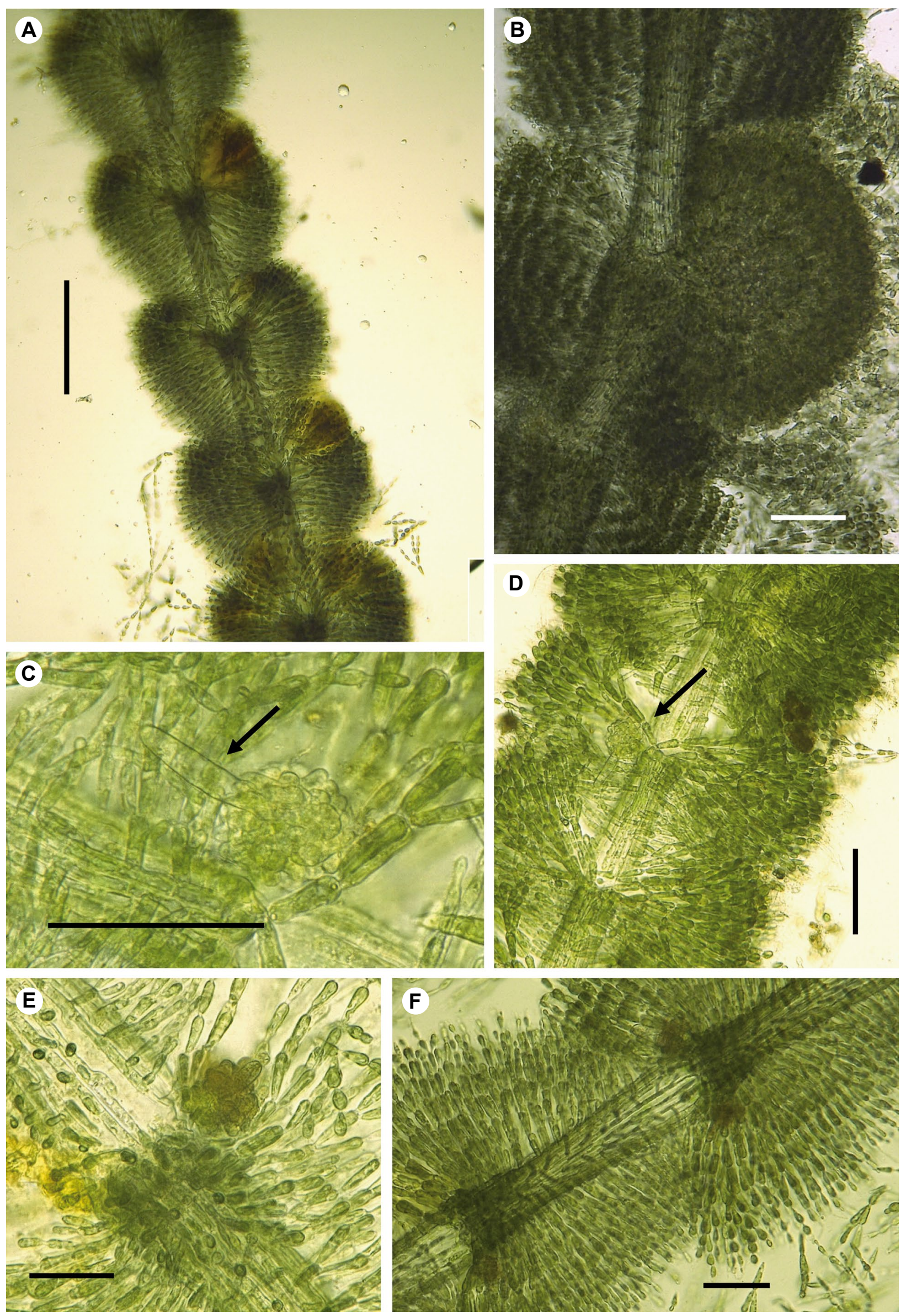

Figure 3. Kumanoa comperei. A, F - whorls with primary and secondary fascicles; B - carposporophyte; C-E - carpogonia with trichogyne (arrow). (A-F, Fischer RW 294/17, AC 039). Scales: A $=250 \mu \mathrm{m} ; \mathrm{B}=100 \mu \mathrm{m}$; C-F $=50 \mu \mathrm{m}$. 

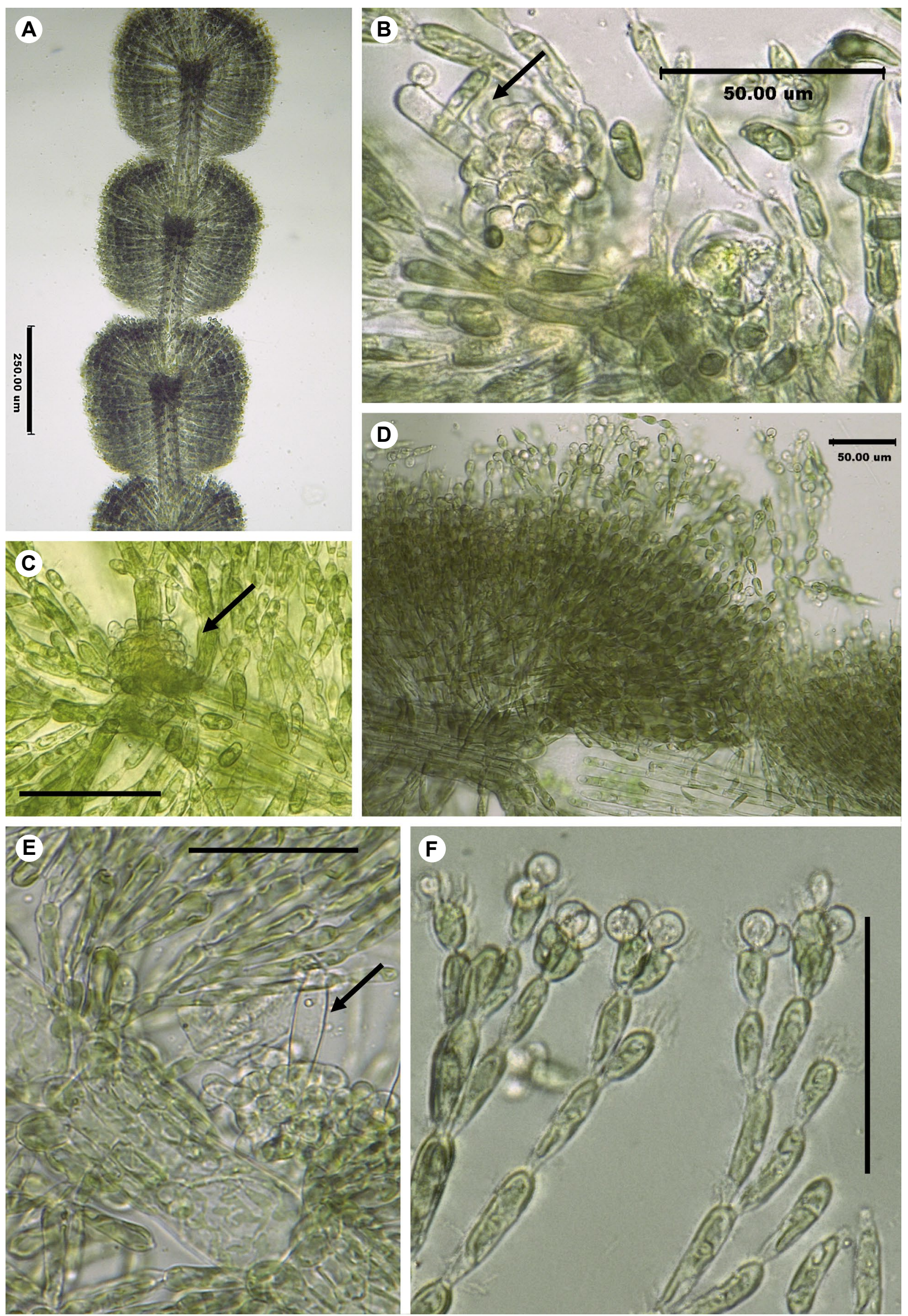

Figure 4. Kumanoa comperei. A - whorl; B-C, E - carpogonium with trichogyne; D - carposporophyte; F - spermatangia; (A-F, Fischer RW 453/16, AC 042). Scales: A $=250 \mu \mathrm{m} ; \mathrm{B}-\mathrm{F}=50 \mu \mathrm{m}$. 

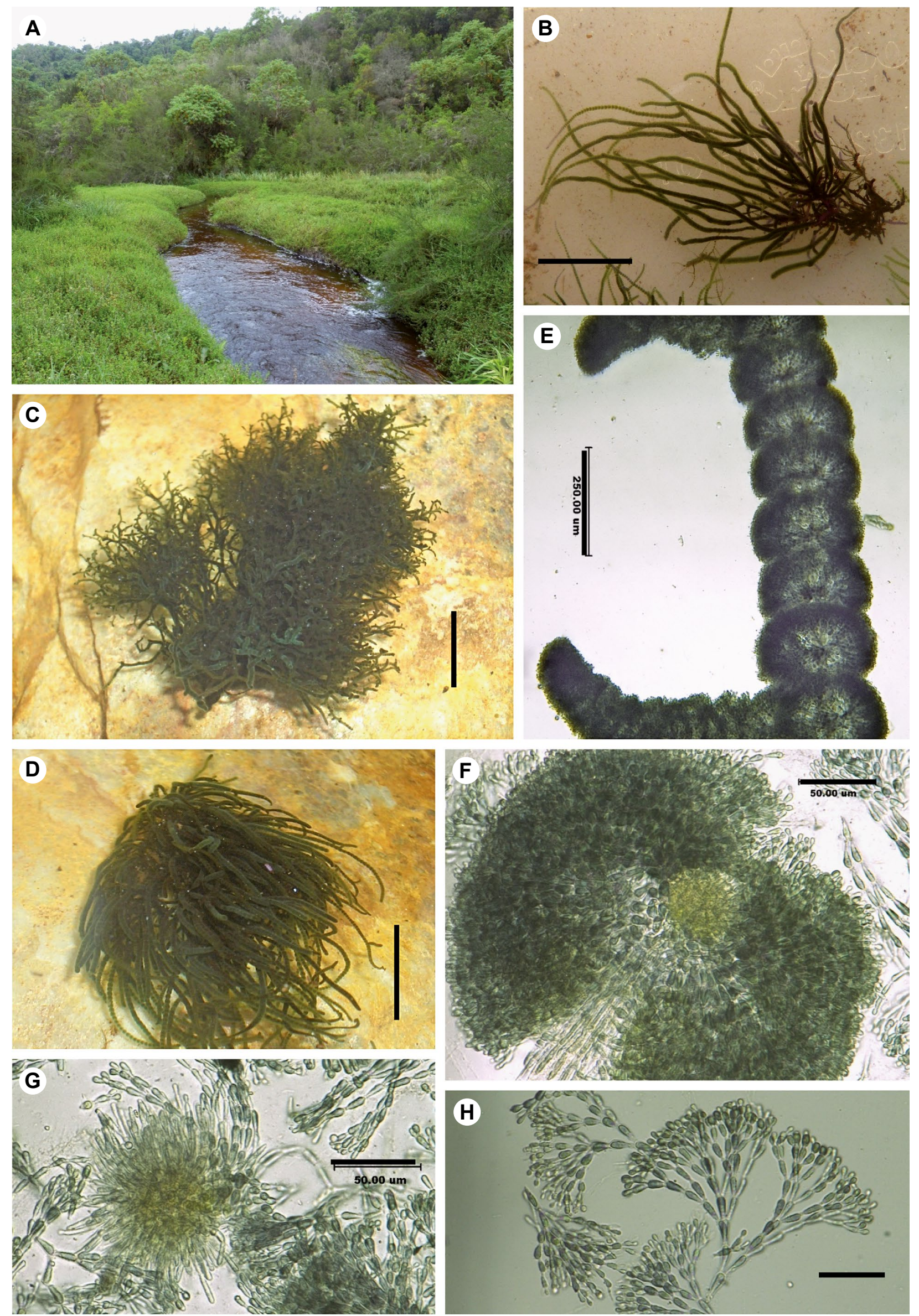

Figure 5. Kumanoa rwandensis. A - Habitat with Rwasenkoko stream, Rwanda; B-D - habit; E - whorls; F - carposporophyte; G - young carposporophyte; H - primary fascicles. (B-H, Fischer RW 678/17, AC 068). Scales: B-D $=1 \mathrm{~cm} ; \mathrm{E}=250 \mu \mathrm{m} ; \mathrm{F}-\mathrm{H}=50 \mu \mathrm{m}$. 


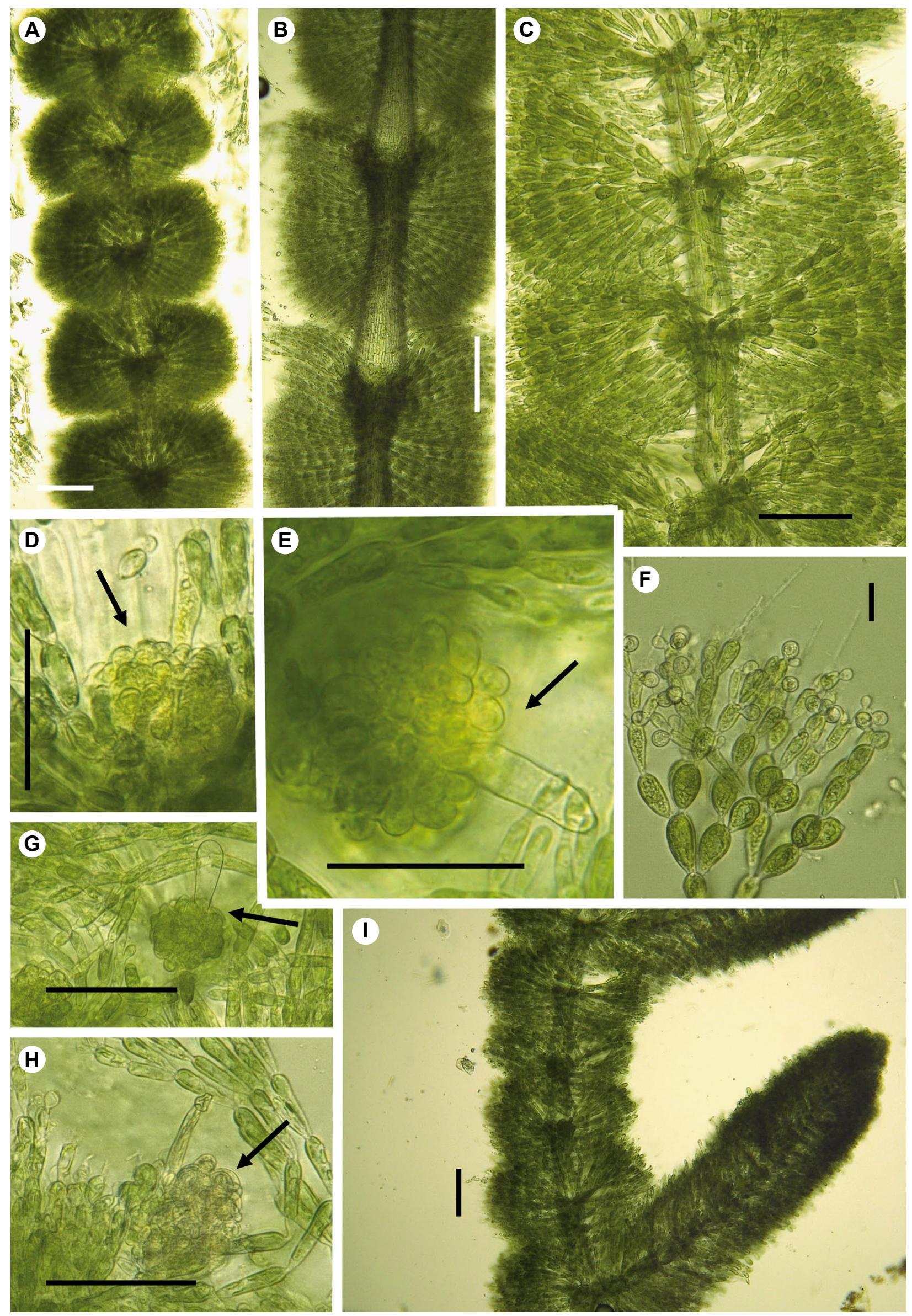

Figure 6. Kumanoa rwandensis. A-C, I - whorls; D-E, G-H - carpogonium with trichogyne (arrow); F - spermatangia. (A-F, Fischer RW 678/17, AC 068). Scales: A-C, I $=100 \mu \mathrm{m}$; D-E, G-H $=50 \mu \mathrm{m} ; \mathrm{F}=10 \mu \mathrm{m}$. 
up to $100-119 \mu \mathrm{m}$ long and $210-241 \mu \mathrm{m}$ in diameter, gonimoblast filaments $6-8$ cell-storeys, carposporangia obovoid or elliptical, 4-4.5 × 6-7 $\mu \mathrm{m}$.

Ecology and distribution. Kumanoa rwandensis is found in acidic streams in Rwasenkoko swamp, surrounded by a vegetation of Cyperus denudatus, Cyperus aterrimus and ericaceous shrubs (Erica rugegensis, Hypericum revolutum, Cliffortia nitidula, Anthospermum usambarense) and Hagenia abyssinica. The populations grow on quartzitic stones together with Chantransia stages of Sheathia (see below). An aquatic macrophyte occurring in the stream is Potamogeton thunbergii. The second locality is an open sunny and fast-flowing stream outside the forest, the Rukarara, which later becomes the Nyabarongo and Akagera and thus one of main sources of the Blue Nile. There Kumamoa rwandensis is associated with several yet-unidentified freshwater red algae and a new species of Paralemanea (Fischer et al. in prep.).

Notes. In the phylogenetic tree (Fig. 1), Kumanoa rwandensis clusters with Kumanoa ambigua, known from Central America to northern South America, and K. gudjewga M. L. Vis et al. from Australia. It differs from Kumanoa ambigua and K. gudjewga in the distinctly shorter secondary fascicles and the carposporophyte being as high or higher than the whorl radius $[120-300(-450) \mu \mathrm{m}$ in $K$. ambigua, $150-410(-600) \mu \mathrm{m}$ in $K$. gudjewga, up to 119 $241 \mu \mathrm{m}$ in K. rwandensis]. The carposporangia of Kumanoa rwandensis are much smaller $(4.5-7 \mu \mathrm{m})$ than those of K. ambigua $(10-17 \mu \mathrm{m})$ and $K$. gudjewga $(14-26 \mu \mathrm{m})$.

Specimens examined. RWANDA. Southern Province, Rukar-

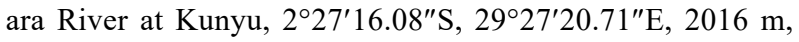
E. Fischer 682/17 (AC 071), 8 September 2017 (KOBL).

\section{The new genus Ahidranoa}

While comparing two samples of a freshwater red alga, they seemed at first similar to the Southern Hemispherean genus Nocturama that was established to accommodate a single species from Australia and New Zealand, Batrachospermum antipodites (Entwisle 1995). This species was formerly included in a cluster of Australian and New Zealand species that was distinguished by carpogonia subtended by a relatively short filament of modified cells (Entwisle \& Foard 1997, 2007). The other taxa included in this cluster are now placed in the expanded genus Nothocladus (Entwisle et al. 2016). Necchi et al. (2016) described a second species of Nocturama, N. novamundensis (Necchi et al. 2016) from Brazil, Rio Grande do Sul. Molecular evidence, however, supports the recognition of a new genus. This taxon is well supported as sister to a clade with Sirodotia, Lemanea, Batrachospermum s.str. and Tuomeya (Fig. 1). Nocturama, on the other hand, is sister to Nothocladus, Torularia and Sheathia.

Ahidranoa Eb. Fisch., Killmann \& D. Quandt, gen. nov.

Diagnosis: Ahidranoa is similar to Batrachospermum s.str. and Nocturama but is characterized by curved primary fascicles, the presence of rather abundant secondary fascicles, the curved and shorter cells of the carpogonial branches different from primary fascicle cells, and the pear-shaped trichogyne which is widest in the lower third.

Generic type: Ahidranoa madagascariensis Eb. Fisch., Killmann \& D. Quandt

Etymology. The name of the new genus is derived from the Malagasy word for alga: ahidrano.

\section{Ahidranoa madagascariensis Eb. Fisch., Killmann} \& D. Quandt, sp. nov.

(Figs 7-8)

Type: Madagascar, Antsiranana, Parc National de Masoala, River Ambanizana, $15^{\circ} 26^{\prime} 59.88^{\prime \prime} \mathrm{S}, 50^{\circ} 00^{\prime} 29.45^{\prime \prime} \mathrm{E}, 335 \mathrm{~m}$, E. Fischer 799/17 (AC 076), 30 September 2017 (TAN - holotype; KOBL - isotype).

Description. Thalli brownish to reddish-brownish, moderately mucilagineous, abundantly and irregularly branched, up 5-8 cm long. Rhizoidal cells not inflated, cylindrical, $120-130 \mu \mathrm{m}$ in diameter. Whorls spherical or barrel-shaped, 150-500 $\mu \mathrm{m}$ in diameter. Internodes 160-280 $\mu \mathrm{m}$ long. Primary fascicles curved, composed of 10-13 cell-storeys, distal cells ellipsoid or obovoid, $380-410 \times 77-80 \mu \mathrm{m}$. Secondary fascicles present, below the whorls of primary fascicles, composed of $2-8$ cell-storeys, not covering the whole internode.

Monoecious. Spermatangia $4.5-6 \mu \mathrm{m}$ in diameter, on primary fascicles. Carpogonial branches straight, composed of 11-13 cell-storys, 234-244 × 80-83 $\mu \mathrm{m}$, differentiated from primary fascicle cells, curved and shorter than primary fascicle cells. Carpogonia symmetric, 30-45 $\mu \mathrm{m}$ long, trichogyne pear-shaped, widest in lower third, sessile, 13-15 $\mu \mathrm{m}$ in diameter. Carposporophyte indistinctly pedicellate to almost sessile, 1 per whorl, dense, spherical, 58-70 $\mu \mathrm{m}$ in diameter, carposporangia obovoid, 4-5 × 5-6 $\mu \mathrm{m}$.

Ecology and distribution. Ahidranoa madagascariensis occurs in the Marojejy Massif in a small shaded stream just below Cascade d'Humbert. The second locality is the River Ambanizana on Masoala presque-île, which is quite sun-exposed. Ahidranoa madagascariensis, however, occurs between the leaves of a member of Podostemaceae and thus is also growing in shade. At the same locality, the new species Sirodotia masoalensis (see below) is growing in full sun. Ahidranoa madagascariensis is so far restricted to northeastern Madagascar.

Specimens examined. MADAGASCAR. Antsiranana, Parc National Marojejy, small stream near Cascade d'Humbert, $14^{\circ} 25^{\prime} 58.3^{\prime \prime} \mathrm{S}, 49^{\circ} 46^{\prime} 22.7^{\prime \prime} \mathrm{E}, 489 \mathrm{~m}$, E. Fischer $28 / 14$, 18 October 2014 (TAN, KOBL).

\section{Evidence for the occurrence of the genus Sheathia in Central Africa}

Two specimens of a bluish grey acrochaetioid alga were collected and tentatively identified as Audouinella. However, molecular data suggest that these are Chantransia stages of the genus Sheathia, and the two accessions accordingly cluster with other Sheathia species, but no mature gametophyte could be detected. 

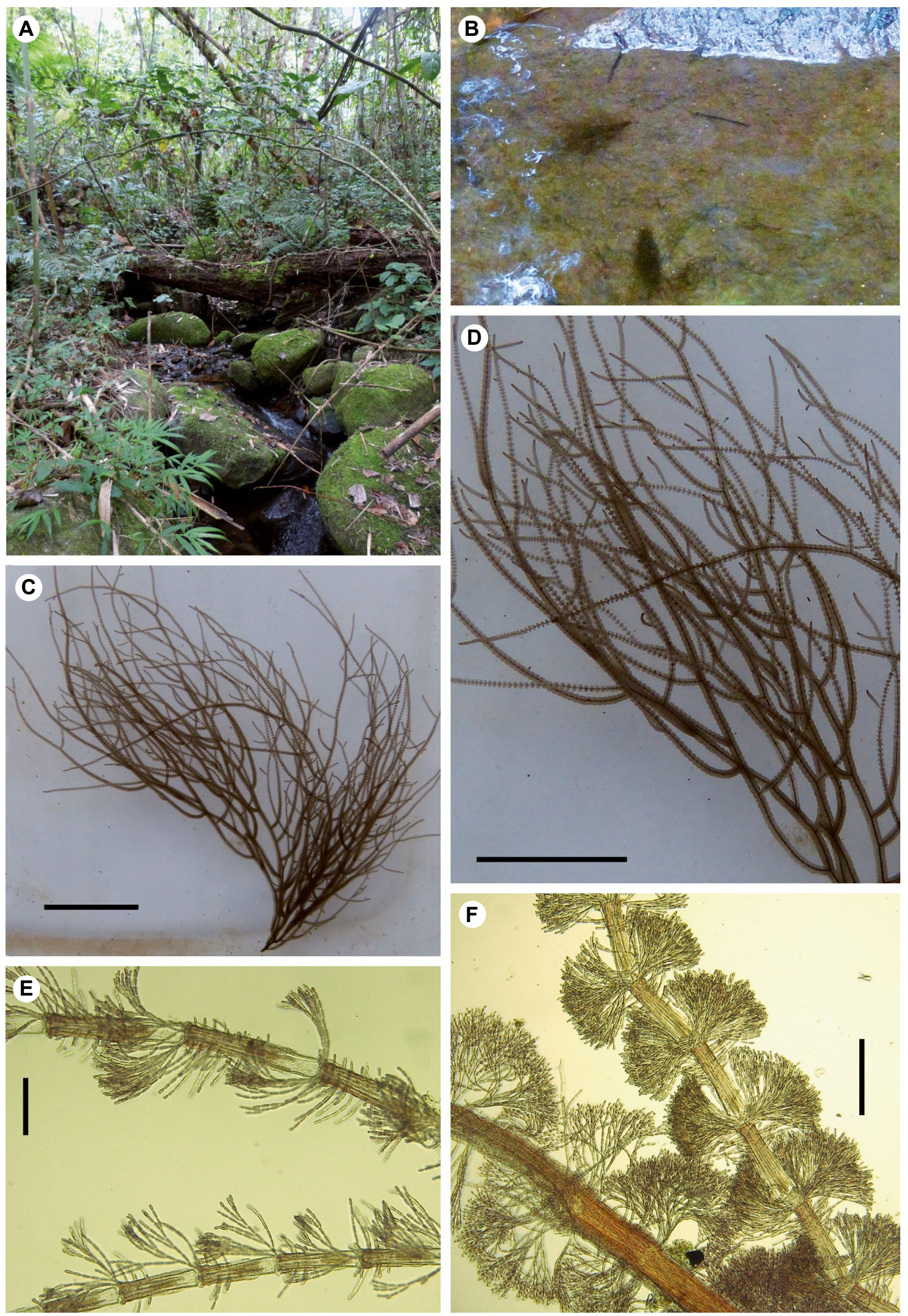

Figure 7. Ahidranoa madagascariensis. A-B - habitat, Parc National Marojejy, Madagascar; C-D - habit, Parc National Marojejy, Madagascar; E-F - whorls. (A-F, Fischer 28/14). Scales: C-D = 1 cm; E-F $=100 \mu \mathrm{m}$. 

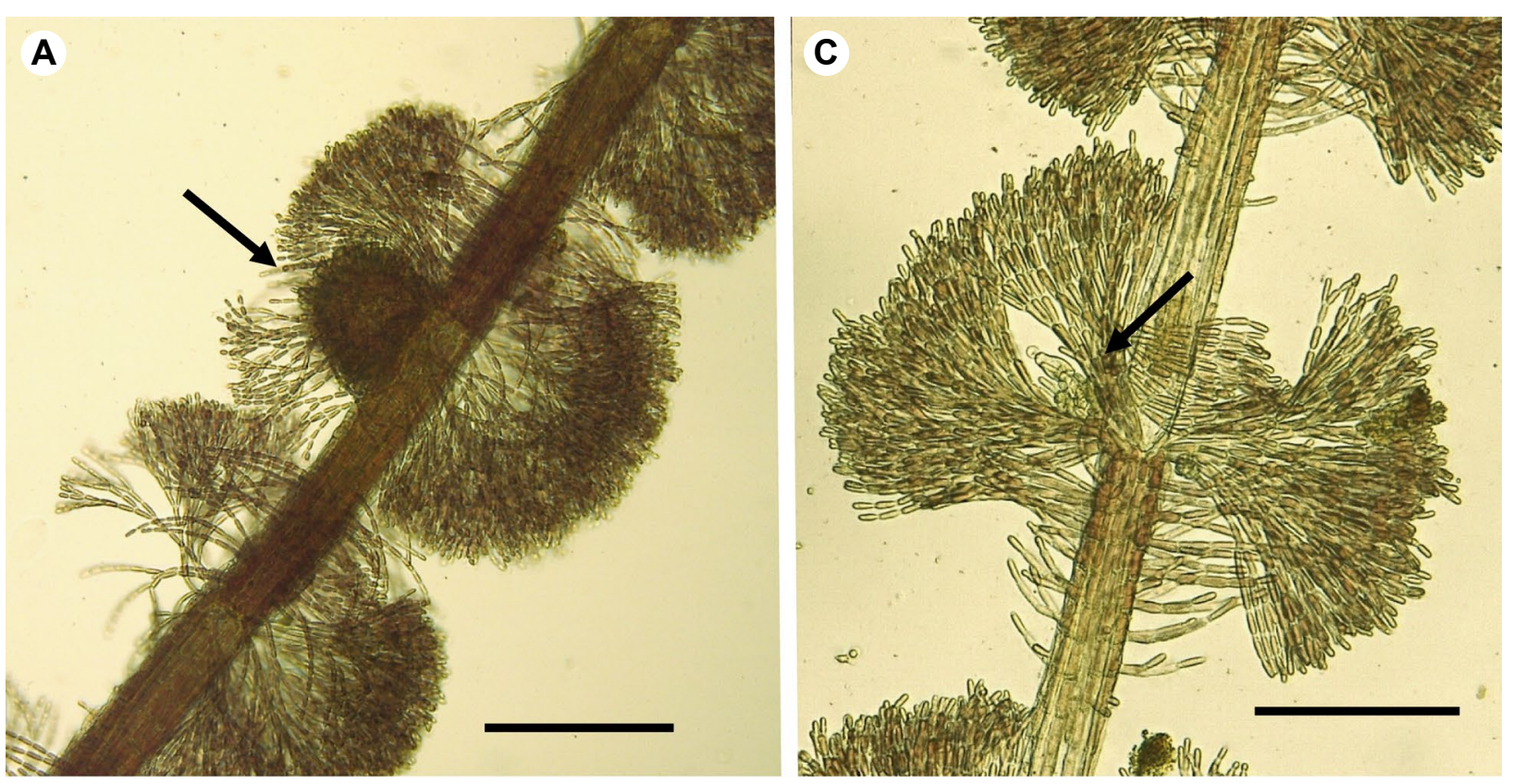

B
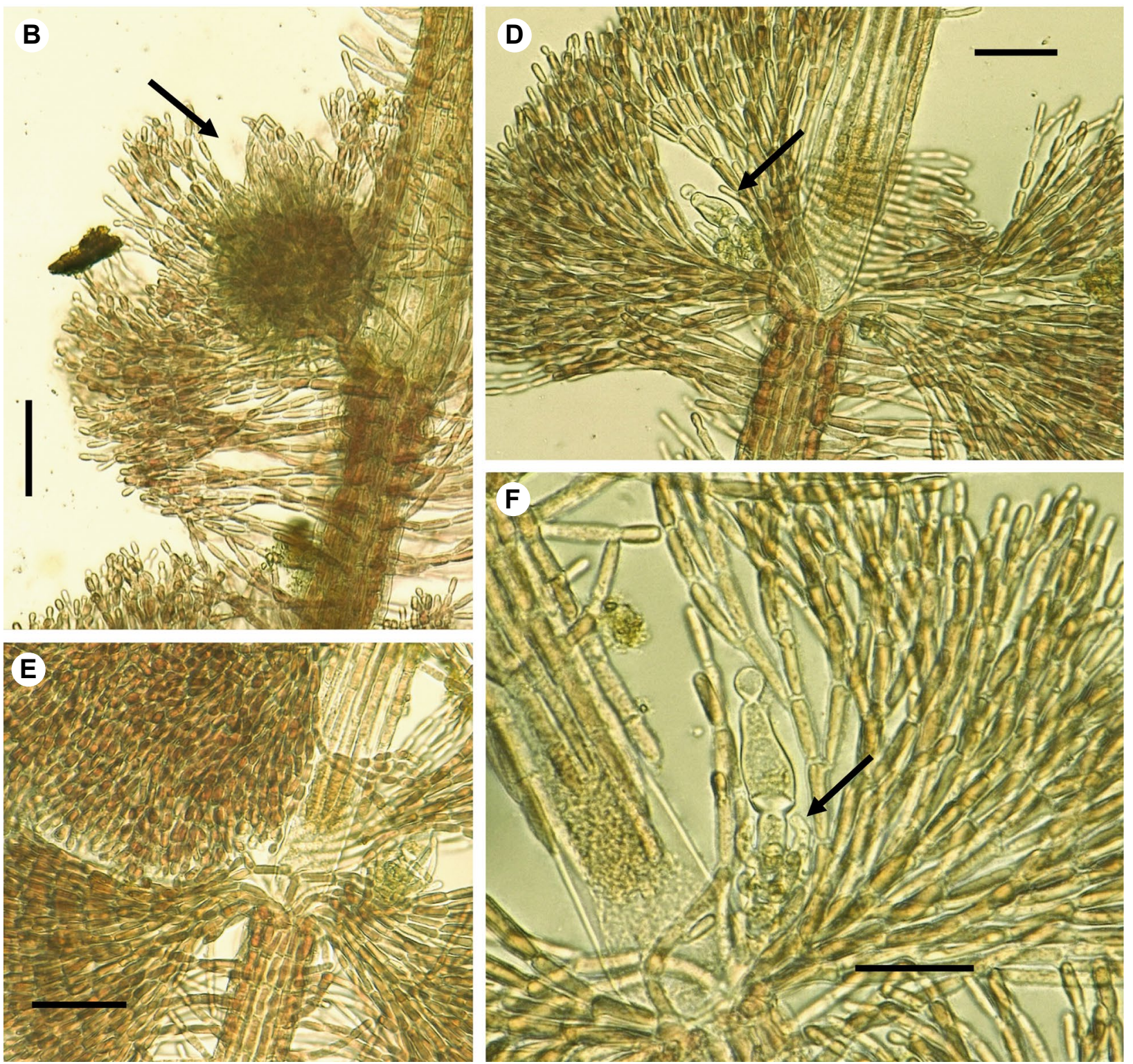

Figure 8. Ahidranoa madagascariensis. A-B - whorl with carposporophyte (arrow); C-D, F - whorls with primary and secondary fascicles, and carpogonium with trichogyne and spermatium (arrow); E - detail of whorl. (A-F, E. Fischer 799/17, AC 076). Scales: A-B = $100 \mu \mathrm{m}$; $\mathrm{C}-\mathrm{E}=50 \mu \mathrm{m} ; \mathrm{F}=20 \mu \mathrm{m}$. 

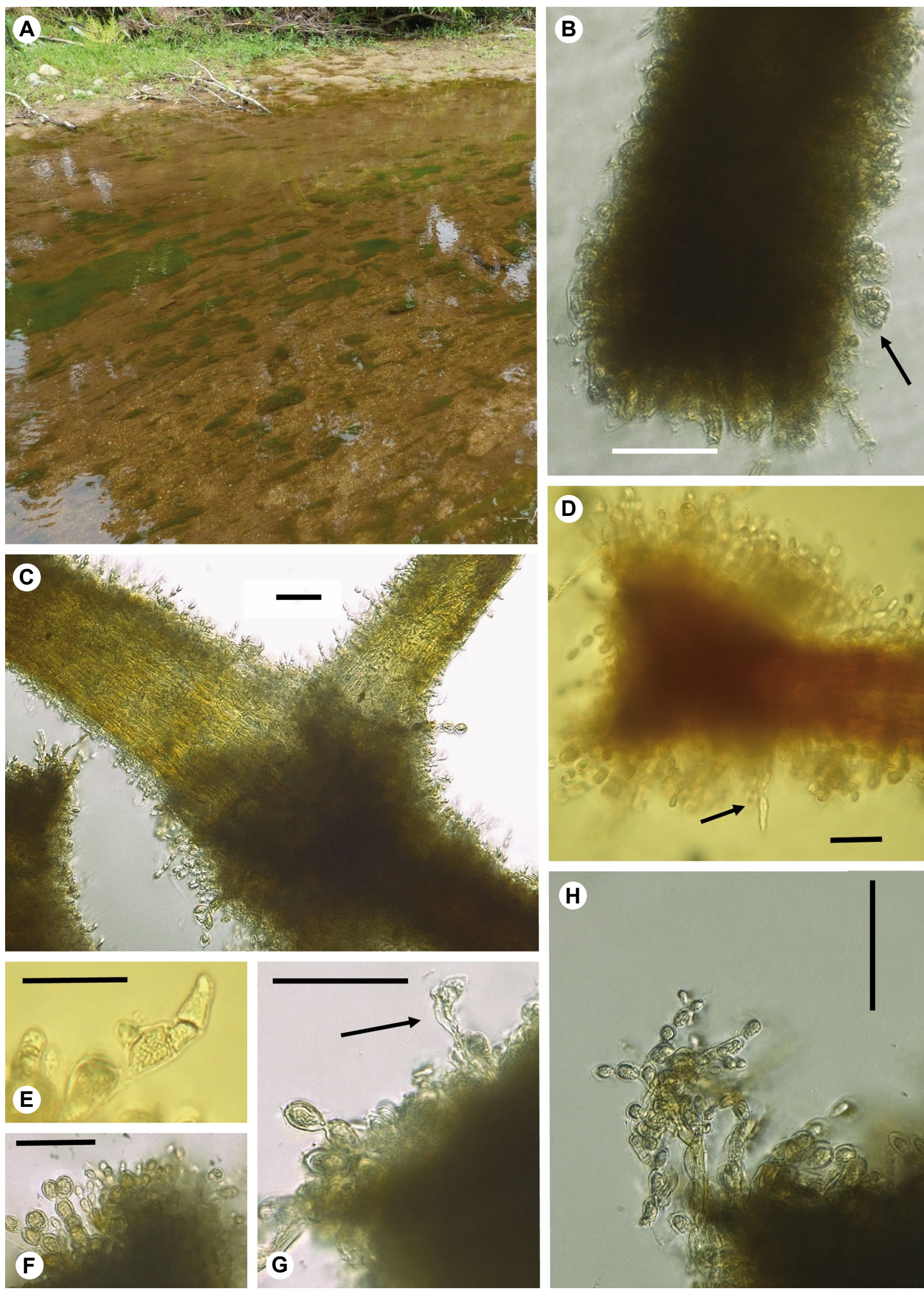

Figure 9. Sirodotia masoalensis. A - habitat; B - whorl with carpogosporophyte and carposporangia (arrow); C - thallus with ramification; D - whorl with spermatangia, and carpogonium with trichogyne (arrow); E, G - young carpogonium (arrow); F, H - carpogonium. (A-H, E. Fischer 181/15, AC 027). Scales: B-C, G-H $=50 \mu \mathrm{m} ; \mathrm{D}-\mathrm{F}=20 \mu \mathrm{m}$. 

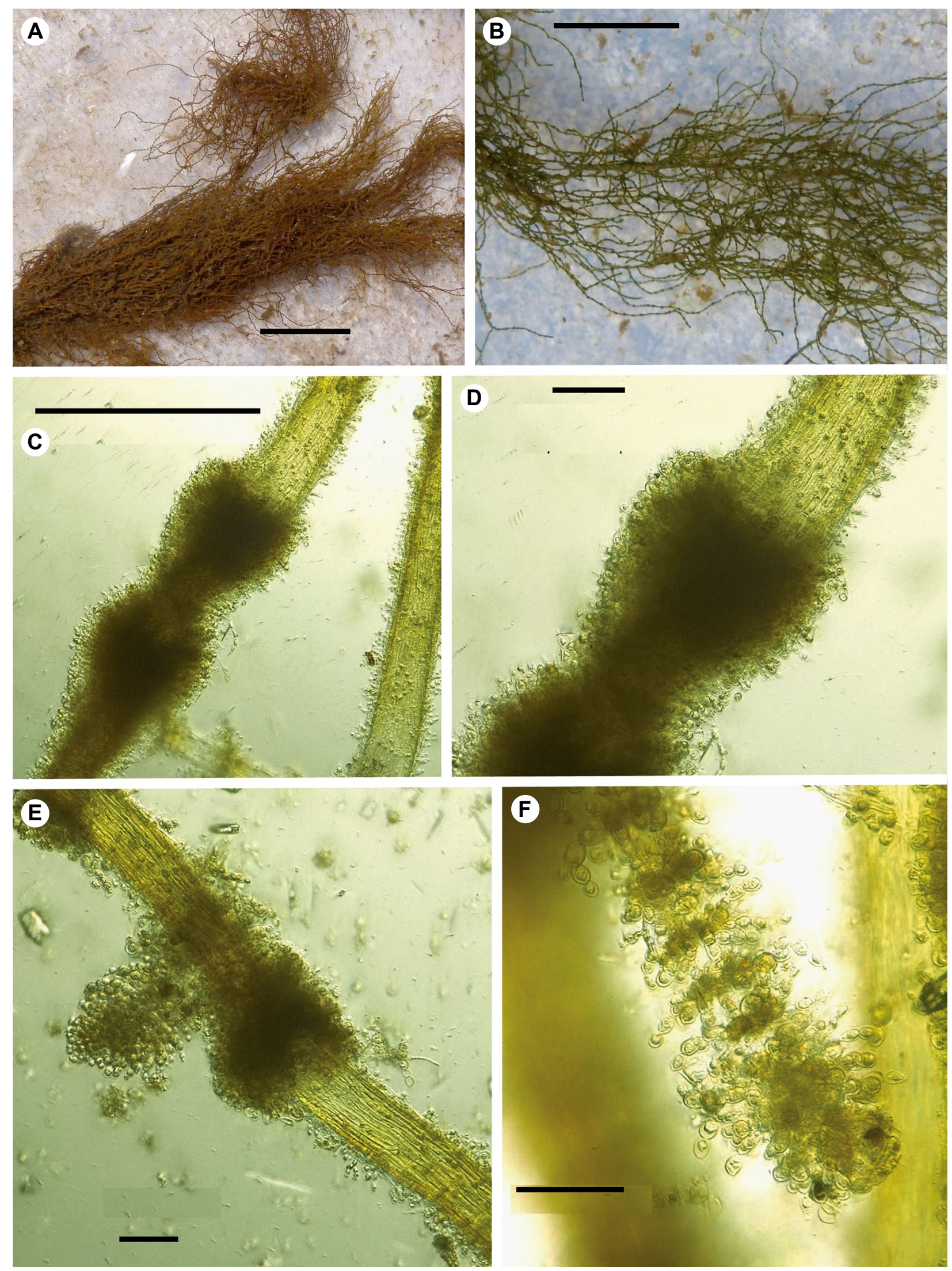

Figure 10. Sirodotia masoalensis. A-B - habit; C-D - whorl with internodes, showing primary and secondary fascicles; E-F - young branch with terminal spermatangia. (A-F, E. Fischer 181/15, AC 027). Scales: A-B $=1 \mathrm{~cm} ; C=250 \mu \mathrm{m} ; \mathrm{D}-\mathrm{F}=50 \mu \mathrm{m}$. 
Skuja (1934) assumed that only the red forms should be included in the genus Audouinella, and that the blue forms are young Chantransia stages of the genus Batrachospermum. Necchi \& Zucchi (1997) support this suggestion. Also, Chen et al. (2014) could show that Audouinella heterospora is the Chantransia stage of Thorea hispida. Given that Szinte et al. (2020) described a Sheathia from northern Zambia as $S$. murpheyi, which was resolved sister to our Chantransia stages, our analysis provides further evidence for the occurrence of Sheathia in Central Africa. However, the species cannot be identified at present, and the genetic differences from $S$. murpheyi might indicate a new species.

Specimens examined. RWANDA. Southern Province, Nyungwe National Park, Rwasenkoko stream, on rocks in Rwasenkoko Swamp, along main road RN6, $2^{\circ} 31^{\prime} 43.60^{\prime \prime} \mathrm{S}$, $29^{\circ} 21^{\prime} 12.62^{\prime \prime E}, 2338$ m, E. Fischer RW 679/17 (AC 069), 8 September 2017 (KOBL); Southern Province, Rukarara River at Kunyu, $2^{\circ} 27^{\prime} 16.08^{\prime \prime}$ S, 29 $27^{\circ} 20.71^{\prime \prime}$ E, 2016 m, E. Fischer RW 687/17 (AC 074), 8 September 2017 (KOBL).

\section{The genus Sirodotia}

Sirodotia was segregated from Batrachospermum, mainly due to the asymmetrical base of the carpogonium and the indeterminate gonimoblast filaments in the carposporophyte (Lam et al. 2012). From the eight taxa accepted by Kumano (2002), Sirodotia goebelii (Entwisle \& Foard $1999)$ was placed in synonymy with $S$. suecica, and $S$. tenuissima was confirmed as a synonym of $S$. suecica (Lam et al. 2012). In Africa, Sirodotia huillensis was described from Angola (see above) but has never been re-collected near the type locality. Material with DNA data has so far only been studied from the United States and Mexico (see Lam et al. 2012). A specimen identified as Sirodotia aff. huillensis from South Africa differed from the samples from Texas, Arizona and Mexico, and could well represent the typical Sirodotia huillensis. Sirodotia suecia is widespread and recorded from the United States, Europe, Australia and New Zealand, and one sample from South Africa. A new species, Sirodotia kennedyi (Szinte et al. 2020), has been described from northern Zambia and is sister to our sample but morphologically differs distinctly, and Sirodotia masoalensis is described here as a new species.

Sirodotia masoalensis Eb. Fisch., Killmann \& D. Quandt, sp. nov.

(Figs 9-10)

Diagnosis: The species differs from S. suecica, S. huillensis and $S$. kennedyi in the much shorter primary fascicles, thus more resembling in its habit Torularia atra. It differs from S. suecica in the lack of terminal hairs on primary fascicles.

Type: Madagascar, Antsiranana, Parc National de Masoala, River Ambanizana, $15^{\circ} 26^{\prime} 59.88^{\prime \prime} \mathrm{S}, 50^{\circ} 00^{\prime} 29.45^{\prime \prime} \mathrm{E}, 335 \mathrm{~m}$, E. Fischer 181/15 (AC 027), 7 October 2015 (TAN - holotype; $\mathrm{KOBL}$ - isotype).

Description. Thalli robust, brownish to reddish-brownish, moderately mucilagineous, abundantly and irregularly branched, up 7-14 cm long. Whorls reduced, obconical to barrel-shaped, $115 \mu \mathrm{m}$ in diameter. Internodes
250-380 $\mu \mathrm{m}$. Primary fascicles straight, composed of 5-6 cell-storeys, branching 3-4 times, distal cells ellipsoid or obovoid, terminal hairs lacking. Secondary fascicles numerous, below the whorls of primary fascicles, composed of 2-3 cell-storeys, straight, up to 20-22 $\mu \mathrm{m}$ long, not covering the whole internode.

Monoecious. Spermatangia spherical, 6-8 $\mu \mathrm{m}$ in diameter. Carpogonial branches arising from intercalary fascicle cells. Carpogonia $26-35 \mu \mathrm{m}$ long, base up to $15 \mu \mathrm{m}$ in diameter, trichogyne indistinctly pedicellate, ellipsoid to cylindrical, $8-10 \mu \mathrm{m}$ in diameter. Carposporangium-bearing filaments extending into outer cortex, carposporangia ellipsoidal, 10-12 $\mu \mathrm{m}$ long and 5-6 $\mu \mathrm{m}$ wide.

Ecology and distribution. Known only from small tributaries of the River Ambanizana on the Masoala Peninsula in Madagascar, where the species is associated with various green algae including Chara sp.

Notes. Sirodotia masoalensis is part of the Sirodotia clade (Fig. 1) and sister to S. kennedyi. Both cluster with S. huillensis and S. delicatula. Several characters of Sirodotia masoalensis, such as the origin of gonimoblast filaments, are not observed, but the new species differs from all congeners in the reduced primary fascicle whorls.

\section{Acknowledgements}

We are grateful to Gilbert Delepierre (Zwevegem, Belgium), Dr. Harald Hinkel (Kigali), Jean-Paul Lebel (Kigali) and Bonny Dumbo (Bukavu), whose support and field research skills were essential to the study, our colleagues from Parc Botanique Zoologique de Tsimbazaza (PBZT, Antananarivo) for their constant support, Claudia Schütte for lab assistance and for cheering up Johanna when she defended her BSc thesis on this project, and Timothy Entwisle and an anonymous reviewer for valuable comments on the manuscript. We thank the Madagascar National Parks (MNP) at Antananarivo and Maroantsetra for research permits, the Direction des Eaux et Forêts (Antananarivo) for export permits, the Rwanda Development Board, Tourism and Conservation (RDB) for good cooperation and for research and export permits, and BMUB (Project 16_III_083_RWA_A_Cyamudongo Regenwald) for financial support of field trips to Rwanda. The first author thanks the Akademie der Wissenschaften und Literatur Mainz for funding support of field trips to Madagascar and Rwanda.

\section{Supplementary electronic material}

Figure S1. Bayesian inference based on $r b c \mathrm{~L}$; posterior probabilities are located along the branches. Download file

Figure S2. Bayesian inference based on COI; posterior probabilities are located along the branches. Download file

\section{References}

Alika, F. O. \& Akoma, O. C. 2012. Preliminary checklist of phytoplankton and periphyton in River Okhuo, Nigeria. Current Research Journal of Biological Sciences 4: 538-543.

Bonnemaison, T. 1828. Essai sur les hydrophytes loculées (ou articulées) de la famille des Épidermées et des Céramiées. Mémoires du Muséum d'Histoire Naturelle, Paris 16: 49-148, pls 3-8. 
Borge, O. 1928. Teil VIII. Süßwasseralgen. In: Schröder, B.: Zellpflanzen Ostafrikas, gesammelt auf der akademischen Studienfahrt 1910. Hedwigia 68: 93-114.

Chapuis, I. S., Necchi, O. Jr., Zuccarello, G. C., Xie, S.-L., Aboal, M., Sánchez Castillo, P. M. \& Vis, M. L. 2017. A new genus, Volatus and four new species of Batrachospermum sensu strict (Batrachospermales, Rhodophyta). Phycologia 56: 454-468.

Chen, L., Feng, J., Han, X.-J. \& Xie, S.-L. 2014. Investigation of a freshwater acrochaetioid alga (Rhodophyta) with molecular and morphological methods. Nordic Journal of Botany 32: 529-535.

Compère, P. 1975. Algues de la region du lac Tchad III-Rhodophycées, Euglénophycées, Cryptophycées, Dinophycées, Chrysophycées, Xanthophycées. Cahiers de l'ORSTOM, série hydrobiologique 9: 167-192.

Da, K. P., Traore, D. \& Assemien, A. P. 1999. Cyanophytes, Rhodophytes, et Pyrrhophytes de la mare et du complexe piscicole du Parc National du Banco (Côte d'Ivoire). Systematics and Geography of Plants 69: 161-183.

De Toni, G. B. 1897. Sylloge Algarum omnium hucusque cognitarum. IV. Florideae Sect. I. - Familiae I-XI. 1-388.

Eloranta, P. \& Kwandrans, J. 1996. Distribution and ecology of freshwater red algae (Rhodophyta) in some central finnish rivers. Nordic Journal of Botany 16: 107-117.

Eloranta, P., Kwandrans, J. \& Kusel-Fetzmann, E. 2011. Süsswasserflora von Mitteleuropa, Bd. 7/Freshwater flora of Central Europe, Vol. 7: Rhodophyta and Phaeophyceae. Spektrum Akademischer Verlag, Heidelberg.

Entwisle, T. J. 1992. The setaceous species of Batrachospermum (Rhodophyta): a re-evaluation of $B$. atrum (Hudson) Harvey and B. puiggarianum Grunow including the description of $B$. dyatyches sp. nov. from Tasmania, Australia. Muelleria 7: 425-445.

Entwisle, T. J. 1995. Batrachospermum antipodites sp. nov. (Batrachospermaceae): a widespread freshwater red alga in eastern Australia and New Zealand. Muelleria 8: 291-298.

Entwisle, T. J. \& Foard, H. J. 1997. Batrachospermum (Batrachospermales, Rhodophyta) in Australia and New Zealand: New Taxa and emended circumscriptions in sections Aristata, Batrachospermum, Turfosa and Virescentia. Australian Systematic Botany 10: 331-380.

Entwisle, T. J. \& Foard, H. J. 1999. Sirodotia (Batrachospermales, Rhodophyta) in Australia and New Zealand. Australian Systematic Botany 12: 605-613.

Entwisle, T. J. \& Foard, H. J. 2007. Batrachospermales. In Entwisle, T. J., Skinner, S., Lewis, S. H. \& Foard, H. J. (eds) Algae of Australia: Batrachospermales, Thoreales, Oedogoniales and Zygnemaceae, pp. 1-25. ABRS, Canberra, CSTRO Publishing, Melbourne.

Entwisle, T. J., Vis, M. L., Chiasson, W. B., Necchi, O. Jr. \& Sherwood, A. R. 2009. Systematics of the Batrachospermales (Rhodophyta) - A synthesis. Journal of Phycology 45: 704-715.

Entwisle, T. J., Johnston, E. T., Lam, D. W., Stewart, S. A. \& Vis, M. L. 2016. Nocturama gen. nov., Nothocladus s.lat. and other taxonomic novelties resulting from the further resolution of paraphyly in Australasian members of Batrachospermum (Batrachospermales, Rhodophyta). Journal of Phycology 52: 384-396.

Evans, J. R., Chapuis I. S. \& Vis, M. L. 2017. Adding to the freshwater red algal diversity in North America: Lympha mucosa gen. et sp. nov. (Batrachospermales, Rhodophyta). Algae 32: 171-179.

Fritsch, F. E. 1907. The Subaerial and Freshwater Algal Flora of the Tropics. Annals of Botany 82: 235-275.

Fritsch, F. E. 1914. Contributions to our knowledge of the freshwater algae of Africa. I. Some freshwater algae from Madagascar. Annales de Biologie Lacustre 7: 1-20.

Ganesan, E. K. \& West, J. A. 2013. Nomenclatural changes for some freshwater red algae from India. Algae 28: 45-51.

Guiry, M. D. in Guiry, M. D. \& Guiry, G. M. 2019. AlgaeBase. Worldwide electronic publication, National University of Ireland, Galway. http://www.algaebase.org [searched on 5 April 2019]
Johnston, E. T., Lim, P.-E., Buhari, N., Keil, E. J., Diawad, M. I. \& Vis, M. L. 2014. Diversity of freshwater red algae (Rhodophyta) in Malaysia and Indonesia from morphological and molecular data. Phycologia 53: 329-341.

Kozlov, A. M., Darriba, D., Flouri, F., Morel, B., \& Stamatakis, A. 2019. RAxML-NG: A fast, scalable, and user-friendly tool for maximum likelihood phylogenetic inference. Bioinformatics, btz305 doi:10.1093/bioinformatics/btz305

Kumano, S. 2002. Freshwater red algae of the world. Biopress Ltd., Bristol.

Kützing, F. T. 1849. Species Algarum, VI. Lipsiae F. A. Brockhaus.

Kylin, H. 1912. Studien über die schwedischen Arten der Gattungen Batrachospermum Roth und Sirodotia nov.gen. Nova Acta Regii Societatis Scientiae Upsaliensis, Ser. IV, Vol. 3,3: 1-40.

Lam, D. W., Entwisle, T. J., Eloranta, P., Kwandrans, J. \& Vis, M. L. 2012. Circumscription of species in the genus Sirodotia (Batrachospermales, Rhodophyta) based on molecular and morphological data. European Journal of Phycology 47: 42-50.

Lemmermann, E. 1914. Rhodophyceae. In: Mildbraed, J. (ed.) Wissenschaftliche Ergebnisse der Deutschen Zentralafrika-Expedition 1907-1908 unter Führung Adolf Friedrichs, Herzog zu Mecklenburg 2: 94.

Necchi, O. Jr. 1990 Revision of the genus Batrachospermum Roth (Rhodophyta, Batrachospermales) in Brazil. Bibliotheca Phycologia 84: 1-201.

Necchi, O. Jr. \& Vis, M. L. 2012. Monograph of the genus Kumanoa (Rhodophyta, Batrachospermales). Bibliotheca Phycologia 116: $1-79$.

Necchi, O. Jr. \& Zucchi, M. R. 1997. Taxonomy and distribution of Thorea (Thoreaceae, Rhodophyta) in Brazil. Archiv für Hydrobiologie Supplement 118: 83-90.

Necchi, O. Jr., Sheath, R. G. \& Cole, K. M. 1993. Distribution and systematics of the freshwater genus Sirodotia (Batrachospermales, Rhodophyta) in North America. Journal of Phycology 29: 236-243.

Necchi, O. Jr., Entwisle, T. J., Branco, C. C. Z. \& Paiano, M. O. 2016. First record of Nocturama (Batrachospermales, Rhodophyta) in South America, with the description of a new species, N. novamundensis. Phytotaxa 278: 273-280.

Necchi, O. Jr, Agostinho, D. C. \& Vis, M. I. 2018. Revision of Batrachospermum Section Virescentia (Batrachospermales, Rhodophyta) with the establishment of the new genus Virescentia stat. nov. Cryptogamie, Algologie 39: 313-338.

Necchi, O. Jr., Fo, S. G., Paiano, M. O. \& Vis, M. L. 2019a. Revision of Batrachospermum section Macrospora (Batrachospermales, Rhodophyta) with the establishment of the new genus Montagnia. Phycologia 58: 582-591.

Necchi, O. Jr., Garcia Filho, A. \& Paiano, M. O. 2019b. Revision of Batrachospermum sections Acarposporophytum and Aristata (Batrachospermales, Rhodophyta) with the establishment of the new genera Acarposporophycus and Visia. Phytotaxa 395: 51-65.

Rabenhorst, L. 1855. Beitrag zur Kryptogamen-Flora Süd-Afrikas. Pilze und Algen. Allgemeine Deutsche Naturhistorische Zeitung, ser. 2, 1: 280-283.

Rambaut, A., Drummond, A. J., Xie, D., Baele, G. \& Suchard, M. A. 2018. Posterior summarisation in Bayesian phylogenetics using Tracer 1.7. Systematic Biology 67: 901-904.

Ronquist, F., Teslenko, M., van der Mark, P., Ayres, D.-1., Darling, A., Höhna, S., Larget, B., Liu, 1., Suchard, M. A. \& Huelsenbeck, J. P. 2012. MrBayes 3.2: efficient Bayesian phylogenetic inference and model choice across a large model space. Systematic Biology 61: 539-542.

Rossignolo, N. L. \& Necchi, O. Jr. 2016. Revision of section Setacea of the genus Batrachospermum (Batrachospermales, Rhodophyta) with emphasis on specimens from Brazil. Phycologia 55: 337-346.

Rossignolo, N. L., Necchi, O. Jr. \& Guiry, M. D. 2017. Atrophycus, a new genus name for 'Setacea (De Toni) Necchi \& Rossignolo'. Notulae Algarum 26: 1-2. 
Salomaki, E. D., Kwandrans, J., Eloranta, P. \& Vis, M. L. 2014. Molecular and morphological evidence for Sheathia gen. nov. (Batrachospermales, Rhodophyta) and three new species. Journal of Phycology 50: 526-542.

Saunders, G. W. 2005. Applying DNA barcoding to red macroalgae: a preliminary appraisal holds promise for future applications. Philosophical Transactions of the Royal Society of London. Series B, containing papers of a Biological Character. London 360: 1879-1888.

Schmidle, W. 1899a. Algologische Notizen VIII. Batrachospermum Bohneri Schmidle n. sp. Allgemeine Botanische Zeitschrift 5: 2-4.

Schmidle, W. 1899b. Einiges über die Befruchtung, Keimung und Haarinsertion von Batrachospermum. Botanische Zeitung 57: 125-135.

Sheath, R. G., Vis, M. L. \& Cole, K. M. 1992. Distribution and systematics of Batrachospermum (Batrachospermales, Rhodophyta) in North America. 1. Section Contorta. Journal of Phycology 28: 237-246.

Sheath, R. G., Vis, M. L. \& Cole, K. M. 1993. Distribution and systematics of Batrachospermum (Batrachospermales, Rhodophyta) in North America. 3. Section Setacea. Journal of Phycology 29: 719-725.

Sheath, R. G., Vis, M. L. \& Cole, K. M. 1994a. Distribution and systematics of Batrachospermum (Batrachospermales, Rhodophyta) in North America. 4. Section Virescentia. Journal of Phycology 30: $108-117$.

Sheath, R. G., Vis, M. L. \& Cole, K. M. 1994b. Distribution and systematics of Batrachospermum (Batrachospermales, Rhodophyta) in North America. 6. Section Turfosa. Journal of Phycology 30: $872-884$.

Sheath, R. G., Vis, M. L. \& Cole, K. M. 1995. Distribution and systematics of Batrachospermum (Batrachospermales, Rhodophyta) in North America. 7. Section Hybrida. Journal of Phycology 34: 431-438.

Skuja, H. 1964. Weiteres zur Kenntnis der Süßwasserrhodophyceen der Gattung Nothocladus. Revue Algologique n.s. 7: 303-314.

Stöver, B. C. \& Müller, K. F. 2010. TreeGraph 2: combining and visualizing evidence from different phylogenetic analyses. $B M C$ bioinformatics 11: 7 .

Suhr, J. N.v. 1840. Beiträge zur Algenkunde. Flora 23, 19: 289-298.

Szinte, A. L., Taylor, J. C., Abosede, A. T. \& Vis, M. L. 2020. Current status of freshwater red algal diversity (Rhodophyta) of the African continent including descriptions of new taxa (Batrachospermales). Phycologia https://doi.org/10.1080/00318884.2020.1732149.

Thiers, B. M. 2019. Index Herbariorum Upgrade: A Project to Improve Access to Information about the World's Plant and Fungal Collections Assets https://www.nybg.org/science-project/indexherbariorum-upgrade/

Vis, M. L. \& Entwisle, T. J. 2000. Insights into the phylogeny of the Batrachospermales (Rhodophyta) from rbcL sequence data of Australian taxa. Journal of Phycology 36: 1175-1182.

Vis, M. L., Chiasson, W. B. \& Sheath, R. G. 2005. Phylogenetic relationships of Batrachospermum species (Batrachospermales, Rhodophyta) from coastal streams in French Guiana. Phycologia 44: 441-446.

Vis, M. L., Saunders, G. W., Sheath, R. G., Dunse, K. \& Entwisle, T. J. 1998. Phylogeny of the Batrachospermales (Rhodophyta) inferred from $r b c \mathrm{~L}$ and $18 \mathrm{~S}$ ribosomal DNA gene sequences. Journal of Phycology 34: 341-350.

Vis, M. L. \& Sheath, R. G. 1996. Distribution and systematics of $B a-$ trachospermum (Batrachospermales, Rhodophyta) in North America. 9. Section Batrachospermum: description of five new species. Phycologia 35: 124-134.

Vis, M. L., Necchi, O. Jr., Chiasson, W. B. \& Entwisle, T. J. 2012. Molecular phylogeny of the genus Kumanoa (Batrachospermales, Rhodophyta). Journal of Phycology 48: 750-758.

Vis, M. L., Sheath, R. G. \& Cole, K. M. 1994. Distribution and systematics of Batrachospermum (Batrachospermales, Rhodophyta) in North America. 8b. Section Batrachospermum: previously described species excluding Batrachospermum gelatinosum. European Journal of Phycology 31: 189-199.

West, W. \& West, G. S. 1897. Welwitsch's African Freshwater Algae. Journal of Botany 35: 1-7.

Wynne, M. J. 2019. Torularia Bonnnemaison, 1828, a generic name to be reinstated for Atrophycus Necchi \& Rossignolo, 2017. Notulae algarum 89: 1-4.

Zucchi, M. R. \& Necchi, O. Jr. 2003. Blue-greenish acrochaetioid algae in freshwater habitats are 'Chantransia' stages of Batrachospermales sensu lato (Rhodophyta). Cryptogamie, Algologie 24: $117-131$. 